\title{
On Postinitial Aber and Other Syntactic Transgressions: Some Considerations on the Nature of $\mathrm{V} 2$ in German
}

\author{
Nicholas Catasso \\ Ludwig-Maximilians-Universität
}

\begin{abstract}
At least since the seminal works on the clause structure of German (Bierwisch 1963, Thiersch 1978, Den Besten 1983 in the generative framework; Drach 1963 and Höhle 1986 within the Topological Field Model), much attention has been devoted to cases of apparent violation of the strict Verb-Second (V2) word order that characterizes matrix but not embedded clauses in German. In particular, phenomena such as multiply-filled prefield (Müller 2003, 2005, 2013; Speyer 2008; Bildhauer 2011; Müller et al. 2012) and so-called postinitial adverbial connectors (Métrich \& Courdier 1995, Pasch et al. 2003, Breindl 2008, Volodina \& Weiß 2010) in main clauses have been discussed. In this paper, I propose a novel approach to the nature and formal status of V2 in German, showing that a slightly different postulation of its structural features solves the problem of finding ad-hoc solutions to each "deviant" phenomenon.
\end{abstract}

\section{Introduction.}

The description of the exact, cartographic (in the widest sense) structure of German, with particular reference to the position of the finite verb and its external argument (or dislocated object or adverbial), has been the object of a number of studies at least since the 1960's, when Bierwisch (1963) and later Thiersch (1978) on the one hand and Drach (1963) on the other hand proposed a precise representation of the German clause. ${ }^{1}$ Bierwisch and Thiersch, within the generative model, were among the first to achieve an accurate depiction of the syntax of verb movement in German. Adapting their observations to modern terminology, one may conclude that both authors argue that surface V2 is to be seen as an IP

\footnotetext{
The first to sketch the asymmetric architecture of the German clause, with particular reference to the Vfin-V2 distinction, was, in fact, Fourquet (1957), whose observations were captured by Bierwisch in a more accurate way within the generative model.
} 
phenomenon, the verb targeting the $\mathrm{I}^{\circ}$ node. The two analyses differ as follows: Bierwisch treats the constituent occurring before the verb as remaining in the inflectional layer. In contrast, Thiersch assumes a further transformational operation that dislocates the element in preverbal position to the left periphery of the clause, namely, to Spec, $\mathrm{CP}$, in a pre-Rizzi 1997 framework. Later research (in particular, Den Besten 1983) has substantially modified this pattern by arguing that the landing site of the finite verb is the head of CP and that the preverbal element occupies its Spec-position. Thus, a generally agreed-upon representation of $\mathrm{V} 2$ in German looks like 1.

(1)

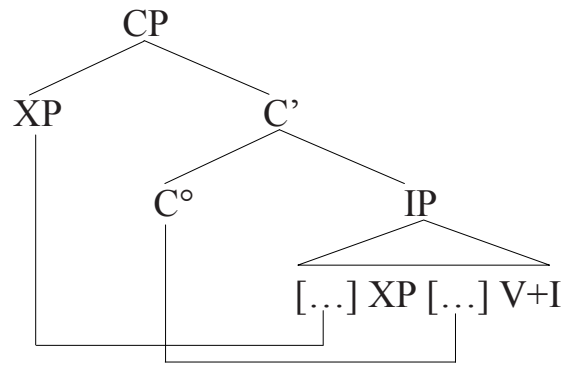

The derivation in 1 only holds for main clauses, since Standard German, together with Dutch, exhibits quite a particular word order as compared to other Germanic languages (see Pysz \& Wiland 2012:340341). Notably, the syntax of German is defined in terms of a distributional asymmetry between independent (or matrix) and dependent (or embedded) clauses, when the latter are introduced by an overt complementizer or a relative pronoun. In particular, main clauses display a V2 word order, in which the inflected (lexical or auxiliary) verb appears in clause-second position, irrespective of the syntactic or semantic role of the element in first position (for example, topic/focus, complement/adjunct, subject/object, agent/theme/patient, etc.).

In contrast, subordinate structures introduced by a complementizer, for instance, that-clauses, or relative constructions - that is, virtually any clause that is not syntactically independent-has a consistent Vfin arrangement retained since Old High German (see Hinterhölzl 2009 and Hinterhölzl 2014 for a discussion of mixed word orders in older stages of 
German). ${ }^{2}$ The underlying OV word order of Standard German implies that the finite verb always occurs to the right of the object (or to the right of the lexical verb in the case of analytical forms) within embedded clauses; it also implies that an overt $\mathrm{C}$ head is always in complementary distribution with V-to-C movement of the verb. ${ }^{3}$ Given this pattern, Den Besten (1983) associates the V2 parameter of German with three fundamental structural features: (i) Subject-Verb Inversion in questions or clauses with a topicalized or focused element (for example, the internal object); (ii) the obligatory second position of the finite verb in the matrix clause; (iii) the exclusive occurrence of V2 in main clauses (this word order is ruled out in embedded contexts).

Since Rizzi's (1997) influential Split-CP Hypothesis, it has been assumed - at least for non-V2 languages - that the left periphery of the clause (what is generally called the $\mathrm{CP}$ ) is in fact made up of a number of projections whose roles and linear distribution are still under debate. The structure in 2 exemplifies Rizzi's (1997) seminal proposal.

\footnotetext{
${ }^{2}$ The case of complementizerless object and predicative clauses, for instance, clauses of the type Hans sagte, er sei krank 'Hans said he is ill', which display the same realization that is possible in English and other languages (such as Italian), are excluded from this discussion for the sake of space. The interested reader is referred to Schwartz \& Vikner 1996:22-23, Reis 1997, Auer 1998, Kiziak 2007:122.

${ }^{3}$ This generalization does not, of course, hold for the phenomenon of so-called substitute infinitives (attested in German and in other West-Germanic languages), whereby, in the case of verbal complexes that consist of an auxiliary and a modal verb selecting a verbal complement, the modal verb is unexpectedly realized in its infinitive form, as in Maria hat das machen wollen/*gewollt 'Mary wanted to do it' lit. 'Mary has this do want.INF/*wanted'. This quirky rule does not affect constructions in which the modal is used as a full verb, as in Maria hätte es gekonnt 'Mary would have been able to do it' lit. 'Mary wouldhave it can.P.PART'. The literature on this phenomenon is vast (see, among others, Gaeta 2010, Sapp 2011, Schallert 2014).
} 
(2)

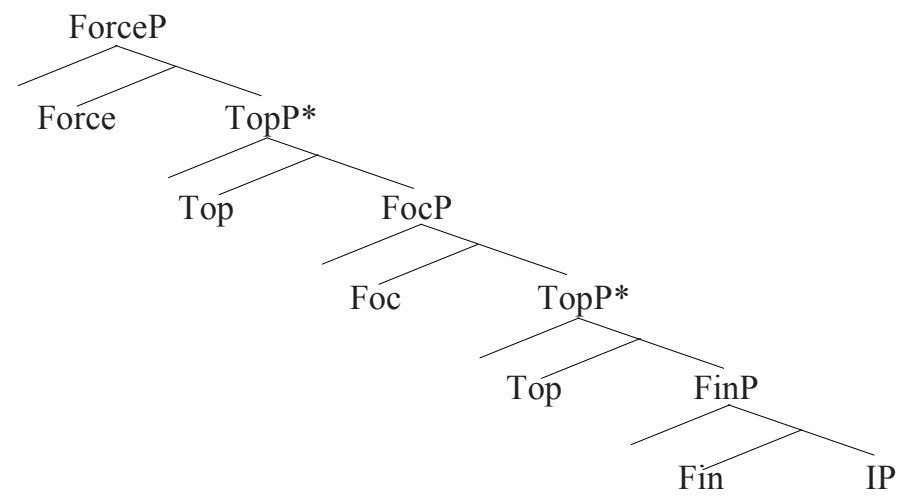

Such a precise differentiation would not be necessary for German. However, the assumption that the basic structure of all languages is the same is convenient. It enables one to describe in a more accurate fashion what kind of element appears before the inflected verb, for example, a Topic (in one of the two positions specified in the structure, depending on the language system) or a Focus (focused DPs, wh-phrases, etc.). ${ }^{4}$ This assumption also enables one to identify the exact position where the clause type is specified (ForceP) and finiteness is marked (FinP). In any case, only one element may precede the inflected verb. This element is generally assumed to target the Fin $^{\circ}$-position in declarative clauses. In the case of embedded structures introduced by a complementizer, the latter resides in Force $^{\circ}$, while the movement of the subject is limited to the specifier of the first available IP-projection (TP, in Pollock's 1989 sense). No other element is allowed to appear in the extended CP. Such a representation is of course supposed to be universally valid.

The Topological Field Model counterpart, first formulated by Drach (1963) and refined by Höhle (1986), makes similar assumptions on the clause structure of German, but represents it in a linear way. This model does not graphically signal the matrix or embedded status of a syntactic string in terms of higher and lower position in the tree. In Höhle 1986, one finds the following descriptive model (slightly simplified here for the sake of convenience):

\footnotetext{
${ }^{4}$ See Frascarelli \& Hinterhölzl 2007 for a more precise hierarchy of topic types in the Split CP.
} 


\begin{tabular}{|c|c|c|c|c|c|c|c|}
\hline clause type & \multicolumn{7}{|c|}{ topological fields } \\
\hline & KOORD & & & C & MF & RK & NF \\
\hline V1 & KOORD & $\mathrm{K}_{\mathrm{L}}$ & & LK & MF & RK & NF \\
\hline V2 & KOORD & $\mathrm{K}_{\mathrm{L}}$ & $\mathrm{VF}$ & $\mathrm{LK}$ & $\mathrm{MF}$ & $\mathrm{RK}$ & $\mathrm{NF}$ \\
\hline
\end{tabular}

Table 1. Höhle’s (1986) Topological Field Model.

In Vfin (VL=Verb-Letzt) or embedded constructions, which may be preceded by a coordinating conjunction (KOORD), a complementizer (C) introduces the clause. The elements of the clause (subject, objects, adjuncts, etc.) occupy the middle field $(\mathrm{MF}=$ Mittelfeld $)$ and the finite verb is hosted in the right bracket position ( $\mathrm{RK}=$ rechte Klammer). Other elements such as question tags, extraposed adjuncts, relative clauses, the second element of a comparative clause, etc. are in the final field $(\mathrm{NF}=$ Nachfeld $)$. In V1 clauses, typically questions and imperative forms, the finite verb may be preceded, apart from a paratactic conjunction, by a left-dislocated element, that is, a topicalized object or adverbial. V2 clauses have the most complex internal structure. Two scenarios are possible in the preverbal layer. First, this position may be filled by a subject, a direct or indirect object, an adverbial, or a topicalized clause (in $\mathrm{K}_{\mathrm{L}}$, or pre-prefield=Vorvorfeld, or in $\mathrm{K}$, or prefield=Vorfeld) immediately followed by the verb. Second, any of these elements may be resumed by a reduced form (a pronoun, or a prepositional object). In V1 and V2 clauses, the right bracket may host the verb particle of the inflected form that appears in the left bracket. The functions described here are exemplified in 3.

(3) a. Vfin Clause

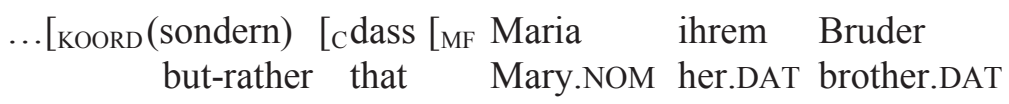

ein Buch ge-schenk-t [RK hat, [NF oder?]]]]

a.ACC book.ACC PTCT-give-PTCP AUX-3SG.PRS or

'...but rather that Mary gave a book to her brother, right?' 
b. V1 Clause

$$
\begin{aligned}
& \text { [KOORD und [KLdeine Katze, [C ist } \\
& \text { and your.NOM cat.NOM AUX-3SG.PRS } \\
& \text { [MF die wirklich [RK weg-ge-lauf-en } \\
& \text { DEM.NOM really V.PRT-PTCP-run-PTCP }
\end{aligned}
$$

[NF gestern Abend?]]]]]

yesterday evening

'What about your cat? Did it really run away yesterday evening?'

c. V2 Clause

$\ldots$ [KоORDaber [KL meinem Papa, [vF dem [C mach-t
but
my.DAT dad.DAT DEM.DAT make-3SG.PRS

$$
\begin{aligned}
& \text { [MF das nichts [RK aus, [NF ja?]]]]]] } \\
& \text { DEM.NOM nothing.ACC V.PRT yes }
\end{aligned}
$$

'...but for my dad that's really not a problem, ok?'

The generative (in particular, the GB/P\&P-based) approach and the Topological Field Model are similar in many respects: The projections assumed in the old standard generative framework have their counterparts in the topological one. However, they differ in that the latter (as well as other theories, such as HPSG, Simpler Syntax, and Categorial Grammar) does not employ transformational movement and derivations to explain word order and grammaticality; instead it limits itself to a more or less detailed description of the clause architecture of German.

The structure of this article is as follows: In section 2, three cases of apparent multiple filling of the German left periphery are discussed, based on the type of elements simultaneously occupying the CP: two full XPs (section 2.1), an XP and a focus particle (section 2.2), and an XP and a topic particle (section 2.3). In section 3, I propose a derivation within the generative framework that accounts for the data in section 2 and relies on the distributional interaction between the categories addressed in this paper, thereby challenging the analyses put forth in the 
literature so far. I conclude that the internal structure of the German clause, despite being subject to the V2 parameter, allows for exceptions in the CP that may be elucidated by means of Rizzi's (1997) proposal on the fine structure of the left periphery.

\section{Can the German Prefield Be Multiply-Filled?}

Although Rizzi's 1997 cartographic mapping and Höhle's (1986) Topological Field Model differ in some points not discussed here, they both provide quite a rigid representation of clause structure. However, a number of main- and embedded-clause phenomena have been observed that seem to contradict and complicate the story, most notably the socalled multiply-filled prefield (Haider 1982; Fanselow 1987; Müller 2005, 2013; Speyer 2008; Bildhauer 2011; Jensen 2012). This term is generally used with reference to three types of constellations: (i) two constituents apparently occupying the preverbal position(s) in the left periphery; (ii) a constituent (generally a DP) followed by a focus particle, both linearized before the finite verb; (iii) a constituent followed by a topicalizing connector, such as aber 'however', nämlich 'namely', schließlich 'finally'. In this section, the three phenomena are addressed by presenting their most relevant features and reviewing the structural analyses that have been proposed in the literature. I address the following question: Is it reasonable to assume a doubly-filled prefield in an otherwise strictly V2 language like German, or is this phenomenon to be considered as an exception to the rule?

\subsection{The "Two-Constituent" Prefield Structure.}

In fact, despite the generalization mentioned above, German allows for more than one constituent in the prefield. This possibility is not limited to spoken or specific dialectal varieties (which would not be a good reason to underestimate the issue anyway), but constitutes a well-formed structure in Standard German. As noted by Speyer (2008:455), the phenomenon was more common in earlier stages of German, notably in Early New High German, but is not even considered by more recent formalizations. Consider the examples in 4.
(4) a. $[\mathrm{PF}[\mathrm{Jm}$
6886. Jar]
in-the.DAT 6886th year.DAT 
[der Großfurst Demetri]] hat den the.NOM grand-duke.NOM Demetri AUX-3SG.PRS he.ACC måchtigen Tatarischen Khünig Mamai ge-schlag-en. mighty.WI Tartarian.WI king.ACC Mamai PTCP-overcome-PTCP

'In the 6886th year, the Grand Duke Demetri overcame the mighty Tartarian king Mamai.' (Speyer 2008:482-483)

b. Die Eihäute tret-en durch den the.NOM.PL caul. NOM.PL. emerge-3PL.PRS through the.ACC

Muttermund hervor, [...] und [PF [in der Regel,] cervix.ACC V.PRT and in the.DAT rule.DAT

[wenn der Muttermund seine höchste when the.NOM cervix.NOM its.ACC highest.WI

$\begin{array}{lll}\text { Ausdehnung } & \text { er-reich-t } & \text { hat,]] } \\ \text { extension.ACC } & \text { PTCT-reach-PTCP } & \text { AUX-3SG.PRS }\end{array}$

platz-en dieselben von selbst.

split-3SG.PRS the-same.NOM.PL of REFL

'The cauls become visible through the cervix, [...] and generally, when the cervix reaches full dilation, they split by themselves.'

(von Siebold 1835:131)

c. Mein Frauchen hat ge-sag-t, my.NOM wifey.NOM AUX-3SG.PRS PTCP-say-PTCP

[pF [so interessiert wie Aaron] [damals]] war ich nicht. so interested as Aaron back.then be.1SG.PRET I NOT 'My wifey said that at that time I was not as interested as Aaron.' (Die weißen Wölfe 2010)

The examples in 4 show that the elements found in the doubly-filled prefield do not seem to be subject to any particular class restrictions. In 
4a, a PP and a DP co-occur; in 4b, an adverbial PP and a temporal clause; in 4c, an adjective and an adjunct. Of course, such cases are not to be confused with phenomena such as left dislocation and hanging topic (see Altmann 1981, Cardinaletti 1989, Nolda 2004):

(5) a. Den Hans, den kenn-e ich seit langem. the.ACC Hans.ACC DEM.ACC know-1SG.PRS I since long.DAT 'Hans I have known for a long time.'

(Cardinaletti 1989:9)

b. Der Hans - ich kenn-e

the.NOM Hans.NOM - I know.1SG.PRS

diesen Kerl seit langem.

DEM.ACC guy.ACC since long.DAT

'Hans - I have known this guy for a long time.' (Nolda 2004:424)

The examples in 5 illustrate the former phenomenon whereby the object DP is left-dislocated to the specifier of TopP and resumed by a demonstrative pronoun in [Spec, FinP] (in the Topological Field Model, den Hans appears in $\mathrm{K}_{\mathrm{L}}$ and the pronoun in the prefield). Both XPs display accusative case. This marks the difference with the hanging topic in $5 \mathrm{~b}$, which does not exhibit the same case as the demonstrative DP in the prefield. For this reason, the clauses in 4 are assumed to exemplify two distinct constructions, which are contemplated both by the generative and the Topological models.

At this point, the question arises as to how the problem may be solved by means of the existing models. Haider (1982), Fanselow (1987), and later Müller $(2003,2005)$ note that the XP types that may appear in that position seem to display a particular connection with the VP. They build, inter alia, on Fanselow's observation that one of the two elements is obligatorily either a PP or a directional phrase. In the analysis developed based on this hypothesis, the two XPs in the prefield are interpreted as one because the surface word order is the result of the topicalization of the whole VP into the left periphery, the VP being headless. This would solve the problem due to the elegant assumption that it is all about a seeming double filling of the prefield area. Haider (1982), Fanselow (1987), and Müller (2003, 2005) propose, therefore, an 
ad-hoc solution that may explain some of the possible cases. However, it is not satisfactory because it does not capture all features of the phenomenon. For instance, it neglects the possibility illustrated in $4 \mathrm{~b}$ that a PP and an embedded clause may appear in the prefield, which is a very common structure both in spoken and written Modern German. If the derivation were obtained by means of a remnant VP topicalization, as proposed by Müller (2003, 2005), two facts would remain unexplained: First, as admitted by Müller (2005) himself, structures such as 6a are ungrammatical, even though clauses of this type, with two objects in preverbal position, seem to be allowed, as shown in $6 \mathrm{~b}$.

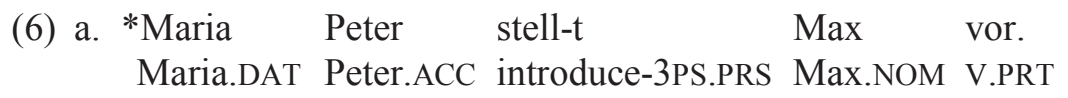

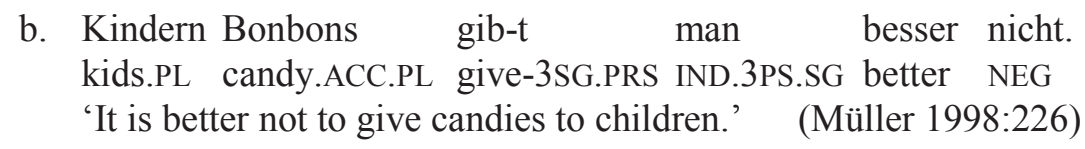

A possible hypothesis could be that the unacceptability of 6a arises from the grammatical relations not being visible in the surface structure, due to the fact that proper names in Standard German do not require a definite article, as would be the case, for example, in Bavarian or Swabian-Alemannic. However, the acceptability of the sentence does not improve even if case relations are made explicit: *Der Maria den Peter stellt der Max vor. It is to be said, however, that even $6 \mathrm{~b}$ is questionable for many speakers (see also Bildhauer 2011), although the order of the constituents in the prefield (DAT $>$ ACC) mirrors the syntactic arrangement within the VP, and case relations are overt: The DP Bonbons 'candies', as a loan word, bears no overt case morpheme, but the DP in clauseinitial position is clearly marked for dative, and the personal pronoun man in the middle field can only be nominative. The grammaticality of the structure may, perhaps, improve if one of the two DPs bears focus stress. This, however, would definitively prevent them from being processed as a single topic. Moreover, it would be difficult to explain clauses with two elements in the prefield, such as a DP and a temporal clause, and a further adjunct $\mathrm{CP}$ that remains attached to the VP.

Consider the examples in 7. 
(7) a. Mein Vater, als er dahinter-kam, my.NOM father.NOM when he.NOM V.PRT-come-3SG.PRET

hat mich nicht ge-schlag-en, AUX-3SG.PRS me.ACC NEG PTCP-beat-PTCP

weil er sauer war, [sondern weil...]. because he.NOM angry be-3SG.PRET but-rather because

'My father, when he found it out, did not beat me because he was mad at me, but because...'

b. Mein Vater, als er dahinter-kam, my.NOM father.NOM when he V.PRT-come-3SG.PRET

hat mich ge-schlag-en, AUX-3SG.PRS me.ACC PTCP-beat-PTCP

bis ich mich kaum noch beweg-en konn-te, until I REFL hardly still move-INF could-1SG.PRET

damit ich ihm sag-e, so-that I him.DAT say-1SG.PRS

warum ich das ge-mach-t hatte. why I DEM.ACC PTCP-do-PTCP AUX-1SG.PRET

'My father, when he found it out, beat me until I could hardly move so that I would tell him why I had done that.'

In $7 \mathrm{a}$, the verb of the main structure is negated to force the interpretation of the causal clause as a central adverbial construction in the spirit of Haegeman 2004. As for 7b, I assume that both the temporal and the final clause are adjoined to VP. Central adverbial clauses (which, roughly speaking, include temporal, conditional, causal, and final subordinates) are, of course, adjoined to the VP. This makes it hard to argue for the movement of a headless VP, which has mein Vater 'my father' as its 
external argument and als er dahinter kam 'when he found out' as an adjunct, but which does not contain the other adjunct $\mathrm{CP}$.

The same goes for $7 \mathrm{~b}$, in which two adjunct CPs remain in the middle field. In particular, it would be bizarre that only one of the adjunct CPs is topicalized, while the other(s) remain adjoined to the (trace of the) VP, irrespective of whether the lexical verb has left the verbal shell (as is the case of synthetic forms) or not (as in analytic forms). In other words, it is unclear what exactly remains in the canonical VP position.

It seems, therefore, that the prefield of the German clause can host more than one element, and that its surface word order in the examples discussed here is not necessarily the result of a remnant VP movement. In the next section, the co-occurrence of an XP and a focus/topic particle or adverbial connector in preverbal position is addressed in order to establish if a similar conclusion may be drawn.

\subsection{The “ $X P+F o c u s$ Particle” Prefield Structure: The Case of Sogar.}

Jacobs (1986) considers nominal expressions occurring in the prefield that are modified by prenominals like sogar 'even' and auch 'also' as a double filling of [Spec, CP]. He argues that a structure of the type [NP [AdvP] $\mathrm{N}$ ] is ruled out for the German nominal expressions, and that, hence, there must be two distinct elements occupying the prefield, as shown in 8 .

(8) a. Sogar er empfiehl-t ihr das Buch. even he.NOM recommend-3SG.PRS her.DAT the.ACC book.ACC 'Even he recommends that book to her.'

(Jacobs 1986:112)

b. Auch meine Oma also my.NOM grandma.NOM

komm-t in Kürze auf dem Bahnhof come-3PS.PRS in short on the.DAT railway-station.DAT

von ihrer Hiddensee-Reise an. from her.DAT Hiddensee-trip.DAT V.PRT

'In a short while, my grandma is also arriving at the railway station from her trip to Hiddensee.' 
Jacobs' argument is valid insofar as in the internal cartography of the German DP, the string AdvP $>\mathrm{NE}$ is not the preferred one. However, Jacobs' observation does not exclude this possibility: Focus particles clearly have a particular relation to the nominal expression that they modify, which led authors such as Reis (2005) and Sudhoff (2010) to postulate an independent projection for such elements, although the question is still debated. The assumption of a DP-internal position for focus particles is, in fact, not a mere speculation: Focus particles, unlike other types of particles, are prosodically integrated into the nominal expression they are associated with (when they are adjacent to it on either right or left), which seems to indicate that they are merged in a position internal to the DP. Moreover, focus particles certainly do not have the same status as full adverbials and DP-internal particles of various kinds that have been discussed for a number of languages, including Japanese (Watanabe 2006), English (Anderson 2014), West Flemish (Haegeman 2013) and even German (Kleemann 2007). In German, the particle can occur not only in prenominal (see 8), but also in postnominal (see 9a,b) position. It can also appear in clause-final position, clearly taking long-distance scope over the DP, which may bear nominative or accusative case, as in $9 \mathrm{c}$ and $9 \mathrm{~d}$, respectively. In addition, focus particles located in the prefield can also take long-distance scope, the focus itself being in the TP in a position lower than that of the finite verb, as in $9 \mathrm{e}$.

(9) a. ... und [sein eig'ner Vater] [sogar] hat and his.NOM own.SI father.NOM even AUX-3SG.PRS

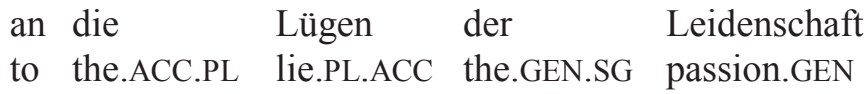

und des Zufalls ge-glaub-t.

and the.GEN fate.GEN PTCP-believe-PTCP

'... and even his father believed the lies of passion and fate.'

b. Viele Menschen, [Freunde] [sogar], many.NOM.PL person.PL.NOM friend.PL.NOM even 
hab-en ein par Wochen nach der Beerdigung have-3PL.PRS a couple weeks after the.DAT funeral.DAT

kein $\mathrm{Ohr}$ mehr dafür, worüber Trauernde no.ACC ear.ACC more PREP.OBJ REL.PRON mourner.PL.NOM

sprech-en woll-en.

speak-INF want-INF

'A couple of weeks after the funeral, a lot of people, even friends, don't feel like listening to what the mourners want to talk about.'

(Die Oberbadische 2013)

c. A: Hab-en heute eigentlich have-3PL.PRS today MOD.PRT

die Geschäfte geöffnet?

the.NOM.PL shop.PL.NOM open

Und wie ist es am Montag?

and how be.3SG.PRS it on.the.DAT Monday.DAT

B: Saublöde Frage! Wie alt bist du?

stupid question how old be-2SG.PRS you.SG

[Meine 10-jährige Tochter]

my.NOM 10 year.old.wI daughter.NOM

$$
\begin{array}{lll}
\text { weiß } & \text { es } & \text { [sogar]! } \\
\text { know-3SG.PRS } & \text { it.ACC.SG } & \text { even }
\end{array}
$$

'A: Are the shops open today? And how about Monday?

B: Bloody stupid question! How old are you? Even my 10-yearold daughter knows that!'

(COSMIQ 2013)

d. Das war ja doch dann alles

DEM.NOM.SG be-3SG.PRET MOD.PRT MOD.PRT then all 
immer frisch. Turkey.PL.ACC have-1PL.PRET we.NOM even always fresh. [Puten] hatten wir [sogar].

'But everything was always very fresh. We even had turkeys.'

e. [Sogar] mag [mein Ehemann] diesen Film, even like-3SG.PRS my.NOM husband.NOM DEM.ACC film.ACC

und er mag keine Sci-Fi normalerweise! and he.NOM like-3SG.PRS no.ACC Sci-Fi.ACC generally

'Even my husband likes that film - and he is generally not a big science-fiction fan!'

Examples 9c,e are admittedly controversial due to the position of the focus particle. In both cases, the context makes it clear that the focused element is not the whole clause but meine 10-jährige Tochter and mein Ehemann, respectively. This is because the content of the two clauses, excluding the focused DP, is thematic and not rhematic, that is, neither the VP nor the internal argument alone are in the scope of the particle. Indeed, both meine 10-jährige Tocher and mein Ehemann must bear focus accent.

In their analysis of focus particle placement in German, Bühring \& Hartmann (2001) conclude that particles such as sogar can only be adjoined to nonargument XPs; they must be maximally close to the nominal expression they take scope over; they can adjoin to CPs, thereby allowing unexpected V3 word orders. Nevertheless, as noted by Reis (2005) in her critical review, the adverb-only theory proposed by Bühring \& Hartmann is defective. For example, it does not account for all possible word orders, and the clauses in 9 exemplify this deficiency. The relative mobility of these particles observed in 9-contra Bühring \& Hartmann's "maximal closeness"- as well as the still unsolved question of focus particle adjunction lead to the conclusion that in cases such as $8 \mathrm{a}$ and 9 , the prefield must be doubly-filled. ${ }^{5}$

\footnotetext{
5 Reis leaves the question of focus particle adjunction open between two options: multiple clause adjunction and direct adjunction to the nominal expression; see also Kleemann 2007 and Speyer 2008.
} 
In any case, all doubt on the (im)possibility for the prefield to be multiply-filled is removed if one considers the examples in 10 .
a. $[\mathrm{pF}$ Meine
Wertsachen,
meine
Mutter, my.ACC.PL valuable-thing.PL.ACC my.ACC mother.ACC

$\begin{array}{lllll}\text { vielleicht } & \text { sogar } & \text { meine } & \text { Frau] } & \text { würde } \\ \text { maybe } & \text { even } & \text { my.ACC } & \text { wife.ACC } & \text { AUX-1SG.SBJV }\end{array}$

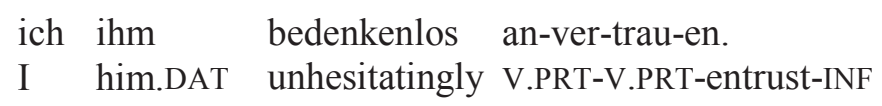

'My valuable things, my mother, maybe even my wife, I would entrust him with everything unhesitatingly.' (Die Welt 2011)

b. [PF Mein Vater, meine Mutter, vielleicht my.NOM father.NOM my.NOM mother.NOM maybe

$\begin{array}{lllll}\text { sogar } & \text { meine } & \text { Frau } & \text { würden } & \text { mit-komm-en. } \\ \text { even } & \text { my.NOM } & \text { wife.NOM } & \text { AUX-3PL.SBJV } & \text { V.PRT-come-INF }\end{array}$

'My father, my mother, maybe even my wife would come.'

Irrespective of how DPs modified by focus particles are treated - that is, whether the particle is analyzed as DP-internal or not-one must admit that the syntactic material residing in the prefield in 10 contains more than one element. More specifically, it includes - minimally — the adverb vielleicht 'maybe' and the complex nominal expression. ${ }^{6}$ The possible

\footnotetext{
${ }^{6}$ Cases such as 8, namely, semiasyndetic coordinations composed of three conjuncts in which only the third element is introduced by an overt paratactic connector, support Borsley's (2005) arguments against the widely accepted view of ConjP as a valid structural representation of coordination. Under this view, the conjunction occupies the head of the phrase and the conjuncts appear in its specifier and complement position. Even treating the structures in 8 as projections of the same conjunction would not solve the problem because of the occurrence of adverbials such as vielleicht at some point in the structure. Such treatment would imply that ConjP could contain more positions for elements
} 
objection that the adverb modifies the focus particle, which is itself an adverb, is obviated by the simple observation that the clause can be reformulated as follows:

(11) a. [pF Mein Vater, meine Mutter, vielleicht meine Frau] würden mitkommen.

b. [PF Mein Vater, meine Mutter, vielleicht meine Frau sogar] würden mitkommen.

c. [ ${ }_{\mathrm{PF}}$ Mein Vater, meine Mutter, sogar meine Frau vielleicht] würden mitkommen.

In 11a, the focus particle is omitted and the focus reading of meine Frau 'my wife' is lost, but the structure is grammatical and still entails a double filling of the prefield. In the other two cases, $11 \mathrm{~b}, \mathrm{c}$, the particle and the irrealis mood adverb are linearized separately, which shows that no dependency relation exists between the two elements. In section 2.3, the syntactic properties of postinitial aber 'but' are discussed as an umbrella case for connectors that may appear in the prefield together with an XP. This discussion puts into question the one-position-oneelement constraint generally assumed for the [Spec, CP] position in German.

\subsection{The "XP+Connector" Prefield Structure: The Case of Aber.}

The German element aber may appear in a number of syntactic environments and, depending on the context, perform different textual or pragmatic roles. Besides its original function as a paratactic connective with adversative value connecting two XPs (clauses, DPs, APs, etc.), aber has developed further pragmatic functions. First, it functions as a modal particle that is base-generated in a low, pre-VP position (MoodP, according to Coniglio 2006) and then moves to a higher functional projection. It also functions as a topic particle with a general denial of expectation reading including a contrastive and a concessive interpretation (Blakemore 2000, Sæbø 2002), whose specific implications are

like this, which in turn would urge the postulation of a Split-ConjP to capture DP-external positions. 
still under debate. In this latter function, aber may appear to the right of an XP located in the prefield, that is, in the so-called postinitial position (Nacherstposition, see Pasch et al. 2003, Onea \& von Heusinger 2009, Volodina \& Weiß 2010), as illustrated in 12a. The same position is available for other adverbial connectors, for example, nämlich 'namely', nun 'now', schließlich 'finally'.

(12) a. Die Partei aber hat gute Juristen. the.NOM party.NOM however have-3SG.PRS good lawyer.PL.ACC 'The party, however, has good lawyers.'

(Die Zeit 2000)

b. Die Universität nämlich steh-t immer the.NOM university.NOM namely stand-3SG.PRS always in enger Beziehung auf das praktische Leben in close.DAT relation.DAT on the.ACC practical.WI lifeACC und die Bedürfnisse des Staates and the.ACC.PL needs.PL.ACC the.GEN state.GEN 'The university, in particular, always stands in close relationship with the practical life and the needs of the state.'

(Humboldt 1956:384)

c. Die Frage nun wäre, the.NOM question.NOM now be-3SG.SBJV

ob sich in deren Schaffen die Wende if REFL in they.GEN work.DAT the.NOM turnaround.NOM

als Zäsur bemerkbar mach-t und ob man as caesura perceivable make-3SG.PRS and if IND.3SG

ihre Musik heute überhaupt anders hör-t. their.NOM music.NOM today anyway differently hear-3SG.PRS

'Now, the question would be if the turnaround is perceivable as a caesura in their work and if their music is listened to in any different way.'

(taz.de 2009) 
d. Für die Frau schließlich ist ihre for the.ACC woman.ACC finally be-3SG.PRS her.NOM

Darstellung in der faschistischen Malerei
representation.NOM in the.DAT fascist.WI art.DAT

erst recht Zuweisung und Einübung in eine Rolle, all-the-more assignment and practice in a.ACC role.ACC

$\begin{array}{lll}\text { die } & \text { sie in der } & \text { Wirklichkeit } \\ \text { REL.PRON.ACC she in the.DAT } & \text { reality[DAT.SG] } \\ & \\ \text { nach-zu-vollzieh-en } & \text { hatte [...]. } \\ \text { V.PRT.INF.MARK.-reproduceI-NF } & \text { have3-PS.PRET }\end{array}$

'Finally, for the woman, her own representation in fascist art means, above all, the assignment and practice of a role which she had to reproduce in everyday life.'

(Ketter 2002:78)

As the examples show, the postinitial element always occurs after the XP in clause-initial position but before the inflected verb, just like focus particles. What crucially differentiates between the elements in 12 and focus particles such as sogar is, inter alia, that the former otherwise function as so-called adverbial connectors, while the latter only perform a focusing function. The term (adverbial) connector is generally used in the literature to refer to these items (see, among others, Pasch et al. 2003, Ferraresi 2008, Volodina \& Weiß 2010, Blühdorn 2012, Karagjosova 2012) However, it seems to me that defining them as connectors when they perform this specific function is misleading, as they do not connect anything, either within the prefield or between two layers (for example, two different CPs or DPs, as a logical connective does). Moreover, in contexts such as 12 they are only homonymous with the corresponding conjunction (aber) and nonconjunctional clause-introducing adverbs (nämlich, nun, schließlich) ${ }^{7}$. I therefore use the term (postinitial) particle

${ }^{7}$ See Besser als ein Mann versteht das Weib die Kinder, aber der Mann ist kindlicher als das Weib 'A woman understands children better than a man, but a man is more childlike than a woman' (Friedrich Nietzsche, Also sprach Zarathustra, ein Buch für Alle und Keinen, chapter 29, 1883-1885); ...sondern 
to indicate the elements in 12 and in particular aber, which is the focus of the present investigation.

The phenomenon, with reference to all or some of the particles observed in 12 , has been variously formalized in the literature, starting from the seminal work by Métrich \& Courdier (1995). The authors point out that there seem to be no constraints whatsoever on the type and syntactic function of the XP appearing in conjunction with aber in the prefield, the most frequent being DPs, followed by PPs, adverbs, infinite verbal forms, verb complexes, connectors, modal adverbs, and negation particles. The syntactic-textual function of postinitial aber is reduced to three basic roles: CONTRAST, RESUMPTION, and TURNING POINT, exemplified in 13-14 below.

Métrich \& Courdier make a clear-cut distinction between contrast and resumption. The former holds when the element in the prefield is semantically similar to an XP in the preceding clause with which an opposition is established. However, the two XPs do not refer to the same entity. The latter holds when the XP occurring with aber resumes the XP (or the information expressed by it) in the preceding clause. For example, that XP can be repeated, replaced by a pronoun, or paraphrased. Contrast and resumption, as defined by Métrich \& Courdier (1995), are exemplified in 13a,b and 13c,d, respectively.
a. Die
Delphier
hielt-en
the.NOM.PL Delphian.PL.NOM
für billig,
und that-en
es;
for suitable and do-3PL.PRET it.ACC
$\begin{array}{lll}\text { die } & \text { Elienser } & \text { aber } \\ \text { the.NOM.PL } & \text { Eleans.PL.NOM } & \text { however }\end{array}$

das

hold-3PL.PRET DEM.ACC

aus logischen Gründen, nämlich weil der Materie kein bestimmtes räumliches Quantum zu applizieren sei, [...] '...but for logical reasons, namely because no definite quantum can be applied to matter [...]' (Johann Friedrich Herbart, Lehrbuch zur Psychologie, 1816); Nun wäre das Problem nicht so gewaltig, wenn sich dieses Phänomen auf Japan beschränkte 'Now, the problem would not be so serious if the phenomenon were limited to Japan' (Die Zeit, 1987); Schließlich haben die Meiler in den vergangenen Jahrzehnten für üppige Gewinne gesorgt 'After all, the nuclear reactors ensured ample profits in the past decades' (Der Spiegel 2014). 
woll-ten es nicht thu-n.

want-3PL.PRET it.ACC NEG do-INF

'The Delphians considered that as proper, and did it; the Eleans, however, didn't want to do it.'

(Schlosser 1972:230)

b. Die einen woll-en, dass ich mich the.NOM.PL one.PL.NOM want.3PL.PRS that I REFL

für die Frauen einsetz-e.

for the.ACC.PL women.PL.ACC V.PRT-appoint.1SG.PRS

Die anderen aber hab-en so viele the.NOM.PL other.PL.WI however have-3PL.PRS so many.ACC.PL

Vorurteile gegen Frauen in der Politik prejudices.PL.ACC against women.PL.ACC in the.DAT politics.DAT wie manche der Männer.

as some.NOM.PL the.GEN.PL man.PL.GEN

'Some want me to support women. Some others, however, have as many prejudices as many men.'

(Westle 2009:228)

c. Würde unsere Wirtschaft Jahr für Jahr AUX-3SG.PRS our.NOM economy.NOM year for year mit der gleichen Prozentzahl zu-nehm-en, with the.DAT same.WI percentage.DAT.SG V.PRT-grow-.INF dann würde sie exponentiell und damit bis then AUX.3SG.SBJV it exponentially and PREP.OBJ until ins Unendliche an-schwell-en. in-the.ACC infinite-WI V.PRT-rise-INF

Das aber wäre unmöglich. DEM.NOM but be-3.SG.SBJV impossible.

'If our economy increased by the same percentage every year, it would rise exponentially, possibly ad infinitum. However, this would be impossible.'

(Poller 2008:62) 
d. Er befahl, Tamorita zu mach-en

he order-3SG.PRET Tamorita.ACC to make-INF

für die Kinder, und gab ihnen Kaschiri.

for the.ACC kids.ACC and give-3SG.PRET them.DAT kashiri.ACC

Die Kinder aber woll-ten

the.NOM.PL kids.NOM.PL but want-3PL.PRET

nichts davon ess-en, $[\ldots]$.

nothing.ACC PREP.OBJ eat-INF

'He ordered that tamorita be prepared for the children and gave them kashiri. The children, however, didn't want to eat any of that $[\ldots]^{\prime}$

(Koch-Grünberg 2009:110) ${ }^{8}$

The third function of postinitial aber in Métrich \& Courdier 1995 is a turning point. It consists in introducing an XP in the prefield into the discourse (that is, an XP that has not been used before or whose reference cannot be inferred from the information provided in the preceding clauses). The role of this XP is to signal a change in perspective and construct a mental contrast between a previous state of affairs and the new situation introduced by the XP+aber clause. Typically,

\footnotetext{
${ }^{8}$ Métrich \& Courdier (1995:291-292) also assume the existence of two subcases of contrast and resumption, namely, IMPLICIT CONTRAST and IMPLICIT RESUMPTION. The preverbal element preceding aber is opposed to an element/informational content implicitly expressed in the preceding clause (former), or is in anaphoric relation with it (latter). In both cases, the reference of the preverbal element is more or less inferable from the context. Consider, for example, Noch war Sachsen dem neuen Glauben nicht völlig gewonnen. Militärisch aber lag das Land am Boden 'The new faith was still not firmly implanted in Saxony. Militarily, however, the country was ruined' (Métrich \& Courdier 1995, implicit contrast); Über eine Million Kinder in Deutschland sehen die Welt in falschen Farben. Die meisten Eltern aber wissen nicht, [...] 'Over one million children in Germany have a distorted vision of the world. However, most parents don't know [...]' (Métrich \& Courdier 1995, implicit resumption).
} 
therefore, the XPs occurring before aber have the meaning now, then, etc., as shown in 14.

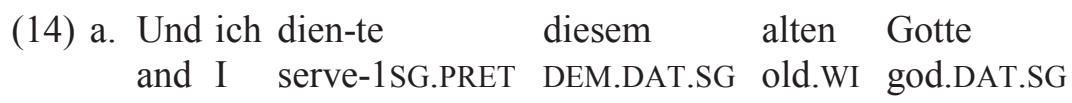

bis zu seiner letzten Stunde.

until to his.DAT last.WI hour.SG

Nun aber bin ich ausser Dienst.

now however be-1SG.PRS I out-of service.DAT

'And I served this old god until his last hour. Now, I am offduty.'

(Nietzsche 1955:497)

b. Ich fand Dialekt-Passagen in Romanen

I find-1SG.PRET dialect-passages.ACC.PL in novel.PL.DAT

früher immer ganz furchtbar, besonders dann, wenn es earlier always quite terrible particularly then if it

lustig sein soll-te. Dann aber

hilarious be-INF shall-3SG.PRET then however

hab-e ich meine Meinung ge-änder-t.

AUX-1SG.PRS I my.ACC opinion.ACC PTCP-change-PTCP

'Earlier I always found passages in dialect in novels quite terrible, particularly if they were supposed to be funny. But then I changed my mind.'

(Montségur Autorenforum 2012)

The functional role that Métrich \& Courdier (1995) assign to postinitial aber is, hence, purely pragmatic. The speaker signals what may be generally defined as a contrast not clearly expressed in the context, that is, he/she disambiguates information that should otherwise be inferred.

Breindl (2008, 2011), who takes into consideration not only aber but also the other postinitial particles, puts forth a slightly different, 
somewhat more general, analysis. She suggests that postinitial elements indicate a topic shift, that is, they are placed after a topic XP which is different from the topic XP of the previous clause. The eligible topic categories for an $\mathrm{XP}+$ aber construction in the prefield are, according to this analysis, shifting, contrastive, and frame-setting topics, while socalled constant topics are not good candidates. Breindl (2008:38-39) investigates the nature of these good candidates with respect to a number of specific features. Shifting topics, the first category identified by the author, represent a linear theme progression, whereby the topic of a clause is the comment of the preceding clause or is derived from it:

(15)

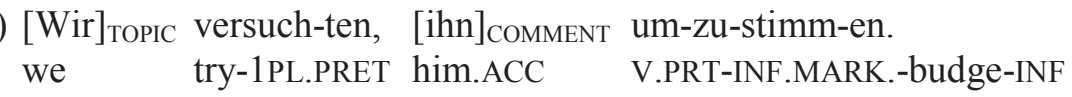

$[\mathrm{Er}]_{\text {TOPIC }}$ aber ließ sich auf keine Weise

$\mathrm{He}$ however let-3SG.PRET REFL on no.ACC way.ACC

zum Weiteressen beweg-en.

to-the.DAT further-eat.DAT move-INF

'We tried to change his mind. However, we did not manage to make him eat further.'

(Breindl 2008:39)

In 15 , the topic of the second clause, which is followed by aber, resumes the comment of the previous clause, a pattern very similar to the one found with Métrich \& Courdier's (1995) resumptive function of aber (see $13 \mathrm{c}, \mathrm{d}$ ).

The second possible constellation is given by contrastive topics. They may be explicit or open to the hearer's implicit mental contrast and correspond quite precisely to the notion of contrast found in Métrich \& Courdier 1995 and exemplified by the original data in 13a,b. ${ }^{9}$

9 The second XP, which formally establishes the contrast in that it is accompanied by the particle, does not necessarily belong to the same syntactic class as its antecedent or surface as a formally similar element. This means that the contrastive interpretation may be implicit, as in Es mag sein, dass er manchmal ein Eichhörnchen ist, sicherlich jedoch hat er weder Hörner noch Klumpfuss, lit. 'It may be that he is sometimes a squirrel, surely however he has neither horns nor clubfoot' (Breindl 2008:31). 

$\begin{array}{llll}\text { (16) }[\text { Die } & \text { Bohrmaschine } & \text { unterm } & \text { Weihnachtsbaum }]_{\text {TOPIC (1) }} \\ \text { the.NOM } & \text { drill } & \text { under-the.DAT } & \text { Christmas-tree.DAT }\end{array}$

[häl-t den Mann verlässlich von der keep-3SG.PRS the.ACC man.ACC reliably from the.DAT

Frau fern $]_{\text {COMMENT(1) }}[\ldots]$

woman.DAT far

[Die Reise nach Mallorca $]_{\text {TOPIC(2) }}$ aber the.NOM trip.NOM to Mallorca.DAT however

[bind-et den Schenkenden und die Beschenkte tie-3SG.PRS the.ACC giver.ACC and the.ACC presentee.ACC

für 2 Wochen aneinander $]_{\operatorname{COMMENT}(2)}$

for 2 weeksACC.PL to-each-other

'The drill under the Christmas tree keeps the husband at a safe distance from his wife. But the trip to Mallorca ties the giver and the presentee to each other for two weeks.'

(Breindl 2008:39, slightly modified)

With reference to frame-setting topics, Breindl (2008:41) observes that one of the main functions of the prefield is to establish a background for the content of the clause or sentence, which may be performed by temporal, local, or other adverbials (defined as "frame adverbials"). Such adverbials act as topics, and their role, following Chafe 1976:50, consists of limiting "the applicability of the main predication to a certain restricted domain." This is illustrated in 17.

(17) Ich bin sicher, daß Margaret selbst

I be-1SG.PRS sure that MargaretNOM.SG even

im Haus Gottes noch weiter-ge-schimpf-t

in-the.DAT house.DAT God.GEN further V.PRT-PTCP-curse-PTCP

hätte, [wenn sie an meiner Seite

AUX-3SG.SBJV if she by my.DAT side.DAT 
$\begin{array}{ll}\text { ge-blieb-en } & \text { wäre }]_{\mathrm{BG}(1)} \text {. } \\ \text { PTCP-remain-PTCP } & \text { AUX-3SG.SBJV }\end{array}$

$[\text { So }]_{\text {CONSTRAST }[B G(1)]}$ aber mach-te

so however make-3SG.PRET

die Sitzordnung ihr das unmöglich.

the.NOM seating-plan.NOM her.DAT DEM.ACC impossible

'I am sure that Margaret would have further sworn even in God's house, if she had remained by my side. The seating plan, however, made that impossible for her.'

(Breindl 2008:41)

As can be seen, both Métrich \& Courdier (1995) and Breindl (2008) mainly focus on the pragmatic features of postinitial aber, without really providing a formal analysis that accounts for its syntactic distribution, bar some preliminary considerations on the possible XP types that allow their combination with a postinitial particle. A formalization of the phenomenon is sketched by Volodina \& Weiß (2010) with reference to nämlich 'namely' (see 12b), who basically consider two possible analyses. One hypothesis, based on Pasch et al. 2003, assumes the availability of an additional projection in the Split CP, where the particle is base-generated. The second, more conservative, hypothesis is that the $\mathrm{XP}$ in the prefield followed by the particle is to be interpreted as one complex: The particle is base-generated in the middle field, projecting its own phrase; the XP moves into the specifier position of this phrase, and the whole PrtP is then moved into the left periphery.

Note that each of the two analyses bears important consequences for the general understanding of the clause structure of German. On the one hand, if the particle were base-generated in the $\mathrm{CP}$, then one should assume that in such cases the prefield is doubly-filled, just as in cases discussed so far. On the other hand, if the PrtP moved to the prefield with the XP in its specifier, the multiple filling of the prefield would only be apparent. An adaptation of Volodina \& Weiß' (2010) structural representation for the latter analysis is given in 18 (representation of $\mathrm{XP}+$ aber derivation). 
(18) a.
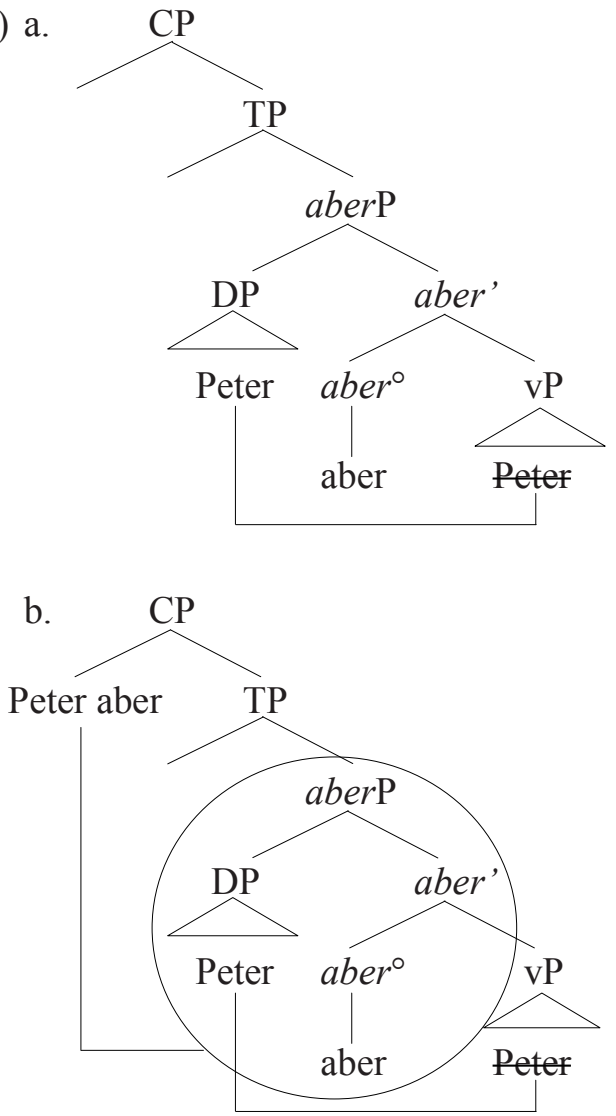

Volodina \& Weiß (2010) bring new data into the discussion exemplified in 19a: An XP in the prefield is modified by a focus particle and followed by a postinitial particle (Volodina \& Weiß focus on nämlich replaced in 19a by aber). They conclude that the second option (that is, 18) is the more plausible of the two and propose a derivation in $19 \mathrm{~b}$, in which the finite verb occupies the head of TopP in the surface structure:

(19) a. Sie selbst aber hat nicht er-kann-t, she.NOM REFL however AUX-3SG.PRS NEG V.PRT-recognize-PTCP 
dass ich es war, $\quad$ der [...].

that I it.NOM be-1SG.PRET REL.PRON.NOM

'She herself has not acknowledged that I was the one who [...]'

(Bible, Hosea 2:8)

b. [TopP sie selbst aber $\left[\right.$ Top $^{\circ}$ hat $]\left[\right.$ FocP $\left[\right.$ FinP $\left[\right.$ Fin $\left.^{\circ}\right][$ TP ... sie selbst aber...]]]]

This analysis would provide a somewhat more elegant solution than the admission that the prefield of a strictly V2 language like German may host more than one element. However, another point must be taken into consideration that makes Volodina \& Weiß' proposal problematic. Consider the examples in 20.

(20) a. Die Tatsache aber, daß es sich the.NOM fact.NOM however that EXPL REFL

bei dem Eastern Airliner um eine Maschine in the.DAT Eastern Airliner.DAT about a.ACC machine.ACC

des Typs Lockheed-"Electra" handel-te, the.GEN type.GEN Lockheed-'Electra' deal-3SG.PRET

schien der Flughafenmannschaft

seem-3SG.PRET the.DAT airport-crew.DAT

eine Katastrophe.

a.NOM catastrophe.NOM

'However, the fact that it was all about a machine of the type Lockheed-'Electra' seemed a catastrophe to the airport crew.'

(Der Spiegel 1960)

b. Der Mann aber, the.NOM man.NOM however der Alles wohl REL.PRON.NOM.SG everything.ACC.SG MOD.PRT 
$\begin{array}{llll}\text { überdacht } & {[\ldots],} & \text { läß-t } & \text { sich weder } \\ \text { roof.3SG.PRS } & \text { let-3SG.PRS } & \text { REFL neither }\end{array}$

$\begin{array}{llll}\text { durch } & \text { diese } & \text { Hindernisse } & {[\ldots]} \\ \text { through noch durch } & \text { DEM.ACC.PL obstacle.PL.ACC } & \text { nor through }\end{array}$

das flache Urtheil des Pöbels

the.ACC flat.WI verdict.ACC the.GEN people.GEN

ab-halt-en oder bestimm-en.

V.PRT.-discourage-INF or affect-INF

'However, the man who is in control of himself lets neither these obstacles nor the flat judgment of common people discourage or affect him.'

(Zeitung für die elegante Welt Berlin: Mode, Unterhaltung, Kunst, Theater 1801:1077)

In 20, a DP that takes a that-clause (20a) or a (restrictive) relative clause (20b) as its complement may appear in the prefield followed by aber and is syntactically detached from its own complement, which is linearized after the particle. If the analysis proposed by Volodina \& Weiß (see 18) were correct, such a structure would definitely be ruled out, since the complex DP, including the dass- or relative clausal complement, should move to the specifier of PrtP already in the middle field and then to a position of the extended left periphery. This, in turn, would raise the question of why the matrix DP appears separate from its complement.

The structure is also possible if the complement of the DP is a nonrestrictive relative clause (as in 21a) or an infinitive clause (as in 21b). Apparently, at least in earlier stages of the language, it was common to have the same structure, but with a DP complement in the form of a PP, as in $21 \mathrm{c}$, or of a genitive phrase, as in $21 \mathrm{~d}$, whereas in Modern German the structure is still present, but less attested.

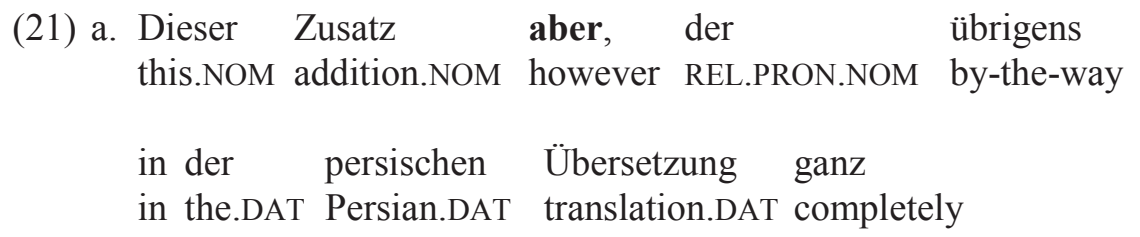


fehl-t, rühr-t ohne Zweifel be-missing-3SG.PRS stem-3SG.PRS without doubt.ACC

von Ibn-Wa'hschijjah her [...].

from Ibn-Wa'hschijjah[DAT.SG] V.PRT

'This addition, however, which is completely missing in the Persian translation, definitely originates from Ibn-Wa'hschijjah.

(Khvolson 2011:143)

b. Die Möglichkeit aber, das eigene Spiel live the.NOM possibility.NOM however the.ACC own.ACC game.ACC live ins Netz zu stream-en, in-the.ACC net.ACC to stream-INF

hat Microsoft gerade ver-schob-en.

AUX.3SG.PRS Microsoft.NOM now V.PRT-postpone.PTCP

'However, Microsoft has postponed the possibility to stream one's own game into the net.'

(Spiegel Online 2013)

c. Der Sohn aber von dieser ist

the.NOM son.NOM however of DEM.DAT AUX.3SG.PRS

nachts ge-storb-en.

at-night PTCP.die.PTCP

'Her son, however, died during the night.'

(Anonymous, Die heiligen Evangelien und Episteln 1830:110)

d. [D]er Sohn aber des Königes hab-e the.NOM son.NOM however the.GEN king.GEN have-3SG.SBJV

aus Mitleiden für die Gefangenen

out pity.DAT for the.ACC.PL prisoners.ACC.PL

bei seinem Vater ge-bet-en, $[\ldots]$.

at his.DAT father.DAT PTCP-beg-PTCP

'However, the king's son, out of compassion for the prisoners, begged his father $[\ldots]$.'

(Weyhenmayer 1701:337) 
A concrete formalization of the structural features and of the positions available in the left periphery of the German clause that would capture the phenomena described in this section seems to be very difficult. In the next section, I bring these facts down to a common denominator by proposing an alternative analysis that is able to derive all the possible word orders found in the prefield.

\section{Discussion and Analysis.}

The puzzling facts discussed in section 2-namely, the presence of multiple XPs in combination with focus and topic particles in the prefield of the German clause - clearly challenge the classical formal analyses proposed in the literature for a general description of the word order possibilities in this language. I have shown that the empirical evidence militates against - or makes difficult the description of - a unified syntactic analysis consistent with the V2 parameter. The question becomes even more complicated if one considers that the three scenarios presented so far may interact with each other in the German prefield, that is, they can occur simultaneously. Consider the examples in 22.

a. Nur die Tatsache aber, daß ein Ereignis only the.NOM fact.NOM however that a.NOM event.NOM

einem anderen zeitlich voraus-geh-t, a.DAT other.DAT temporally V.PRT-precede-3SG.PRS

bedeut-et nicht schon [...].

mean-3SG.PRS NEG already [...]

'Only the fact that an event may precede another temporally does not imply [...]'.

(Schallenberg 2008:210)

b. Gestern aber, als es daran ging, yesterday however as EXPL PREP.OBJ go-3SG.PRET

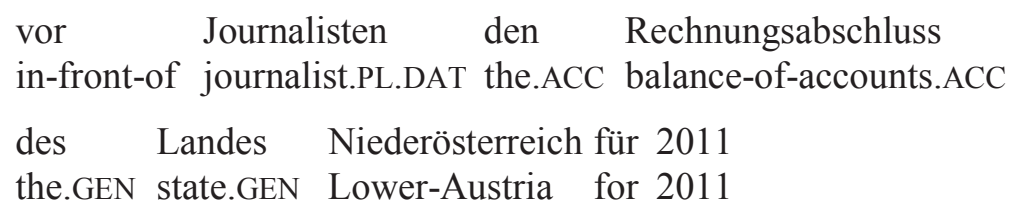


zu präsentier-en, zeig-te sich [...].
to present-INF show-3SG.PRET REFL

'However, yesterday, when the balance of accounts of the state Lower Austria for the year 2011 had to be presented in front of the press, what showed itself was [...].'

(Die Presse.com 2012)

In 22, one observes a combination of the phenomena mentioned so far, for which different analyses were proposed. In 22a, the DP die Tatsache 'the fact' is preceded by a focus particle and followed by the postinitial particle aber. The DP is split in the linearization, since its clausal complement appears after the particle. In $22 \mathrm{~b}$, the temporal adverbial gestern 'yesterday' appears in first position, followed by aber, and another adjunct, a temporal clause in turn complemented by an infinitival clause, follows the particle.

Merging Müller's (2003, 2005) and Volodina \& Weiß' (2010) analyses into a joint model for the representation of 22 would create the same structural problem as the one posed by the single phenomenon, only complicated by the combination of the elements in the same clausal area. For example, for 22a three preliminary principles can be formulated. First, given that the focus particle may also appear in a lower position following the topic particle (see 23a below), it is impossible (contra, for example, Bühring \& Hartmann 2001) for the DP die Tatsache and the focus particle sogar to be processed as one unit, irrespective of the exact word order. Second, even if the nonadjacent DP and the focus particle could be processed as one unit, it would be difficult to explain why the DP is detached from its complement.

Third, the position and derivation of aber, as assumed in Volodina \& Weiß 2010, creates further confusion. Let us suppose that in 22a the phrase that aber follows moves into [Spec, PrtP] in the middlefield. This gives rise to the double problem: One has to explain how the focus particle reaches that position (that is, whether in the middle field or at some other point in the derivation), and what determines the position of the complement that-clause in the prefield. The same applies to $22 \mathrm{~b}$ : It is impossible to adopt Müller's $(2003,2005)$ remnant VP solution in light of the nature and position of the adjunct CP, a fortiori because the two adjuncts are divided by the particle aber, a possibility which is not taken into consideration by Müller. 
(23) a. [D]ie Tatsache aber auch, the.NOM fact.NOM however also

dass etwa ein und derselbe Ort $\mathrm{zu}$

that for-example one and the-same.WI place.NOM to

einer anderen Zeit plötzlich eine andere Bedeutung a.DAT other.WI time.DAT suddenly a.ACC other.SI meaning.ACC

bekomm-en kann, hat Felix Philipp Ingold receive-PTCP can-3SG.PRS AUX.3SG.PRS Felix Philipp Ingold.ACC

bis heute nicht los-ge-lass-en.

until today NEG V.PRT-PTCP-release-PTCP

'But also the fact that for example one and the same place may get another meaning in another time, Felix Philipp Ingold has never released.'

(slightly modified from Jahrbuch z'Rieche 2013)

b. ??Die Tatsache auch aber, dass etwa ein und derselbe Ort zu einer anderen Zeit...

The relative order of the focus particle and the postinitial particle reveals something about the internal structure of the prefield: While the focus particle is mobile, the postinitial topic particle aber always occupies the same position. In light of the data discussed here, it does not seem possible to derive a V2 word order by assuming that a certain number of VP-internal movements result in a single big movement into the $\mathrm{CP}$, whereby giving the impression that the prefield is occupied by more than one element. Therefore,I adopt the tentative hypothesis that under certain particular pragmatic circumstances and without putting into question the validity of the V2 parameter for German, the prefield in this language may host multiple elements.

In what follows, I propose a derivation for all the word orders observed. I begin by considering two parallel perspectives. On the one hand, under the original and largely uninvestigated proposal, focus particles and postinitial particles (which, as we have seen, only affect 
topical elements) may be base-generated in the head of FocP and TopP, respectively, two positions which otherwise remain empty. On the other hand, under the widely accepted view, the general architecture of the left periphery looks like Rizzi's (1997) formalization (see the structure in 2), also taking the two TopP projections to be present in German. ${ }^{10}$

Let me start from the suggestion that the prefield may host two different XPs base-generated in a non-CP position, as shown in 24.

[Mein $\quad$ Vater], $\quad$ als er dahinter-kam],
my.NOM father.NOM as he V.PRT-come-3SG.PRET

$\begin{array}{lll}\text { schlug } & \text { mich } & \text { zusammen. } \\ \text { beat-3SG.PRET } & \text { me.ACC } & \text { V.PRT }\end{array}$

'My father battered me when he found out.'

Given that the DP and the CP are both topics, a possibility to consider would be the analysis in 25: The DP mein Vater moves into the higher [Spec, TopP] and the temporal adjunct clause als er dahinterkam into the lower [Spec, TopP], from the VP-internal position in which they are generated.

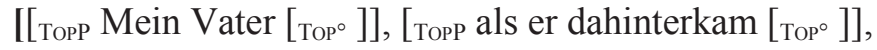
[FinP $\left[\right.$ FiN $^{\circ}$ schlug] $\left.]\right]$ mich zusammen.

As Volodina \& Weiß (2010) note, this is not a particularly problematic issue in the cartographic approach, which predicts that all language systems have the same basic levels of representation. The left periphery of the clause establishes a connection between the content of the inflectional layer and the discourse context or the previous clause/utterance. Therefore, the simultaneous topicalization of two elements - when the speaker needs to push two different elements into the background of the information contained in the IP layer-is not surprising as it is present in a number of languages. Most importantly, one can dispose of a universal set of functional projections to describe

${ }^{10}$ For a more detailed hierarchical representation of topic types in German, see Frascarelli \& Hinterhölzl 2007. 
the phenomenon. Perhaps the multiple filling of the Split CP is not the best option in German; yet it is attested not only in spoken, but also in written language. Moreover, as I have shown, multiple filling was always present in the system.

I propose to combine the hypothesis that in German, the prefield may host multiple elements with the two empirical observations about aber: First, it always occupies the same position in the prefield, that is, it is not mobile (see 23a,b). Second, it may not appear after the second element in the preverbal layer, ergo, after the temporal clause, as in 26a. Then it is possible that aber is base-generated in the head of TopP, the first of the two XPs occupying its specifier, as in $26 \mathrm{~b}$.

(26) a. *Mein Vater, als er dahinterkam aber, schlug mich zusammen.

b. I[Topp Mein Vater [Tоро aber]], [Tорр als er dahinterkam [Tор $\left.{ }^{\circ}\right]$, $\left[\right.$ FiNP $\left[\mathrm{FIN}^{\circ}\right.$ schlug $\left.]\right]$ mich zusammen.

As for unstressed personal pronouns, which are generally argued to be located in [Spec, FinP], one can expect them to move further to [Spec, TopP], as in 27b: As shown in 27c, when more than one XP is present in the pre-Fin area, no other word order is possible. In $27 \mathrm{c}$, aber is, of course, intended in its topicalizing, not in its conjunctional function, in which the particle cannot precede the pronoun.

(27) a. Sie aber, als er ihr von seinen she however when he her.DAT of his.DAT.PL

Erfolgen erzählte, freute sich [...]. success.PL.DAT tell3SG.PRET rejoice3SG.PRET REFL

'However, she was [...] glad when he told her about his successes.’

(Schalit 2001:575)

b. I[TopP $\operatorname{Sie}\left[\right.$ Top $^{\circ}$ aber $]$, [Topp als er ihr von seinen Erfolgen erzählte, $\left.\left[\mathrm{TOP}^{\circ}\right]\right]$, [FINP sie $\left[\mathrm{FIN}^{\circ}\right.$ freute $\left.\left.]\right]\right]$ sich.

c. $\left\{{ }^{\mathrm{OK}} \mathrm{Sie}\right\}$ aber $\left\{{ }^{*}\right.$ sie $\}$, als er ihr von seinen Erfolgen erzählte, $\left\{*^{*}\right.$ sie $\}$ freute sich. 
In section 2.2, I showed that the position of the focus particle is not fixed. I assume, on the basis of this simple observation, that focus particles are DP-internal and therefore move to the CP area together with the nominal expression they are associated with. I also assume that topic particles, which are not mobile, are base-generated in the head of the TopP, whose Spec is targeted by the DP. Given these assumptions, the (partial) derivation of the structure in $28 \mathrm{a}$ is given in $28 \mathrm{~b}$. To explain the apparent mobility of the focus particle, I hypothesize that the DP-internal particle (base-generated in a very high DP-internal Spec position) can move to the higher Top position together with its nominal expression, as shown in $28 \mathrm{~b}$; alternatively, it can remain in a lower position, to which the DP itself (optionally) moves before reaching its surface projection, as shown in 28c. This point is addressed in 32 more thoroughly.

$\begin{array}{llll}\text { a. Dieses treulose Ding } & \text { aber } & \text { auch } \\ \text { this.NOM } & \text { disloyal.wI thing.NOM however } & \text { also }\end{array}$

ist dir sehr gut gelung-en.

be-3SG-PRS you.DAT very well succeed-PTCP

'However, even in this disloyal thing you have succeeded.'

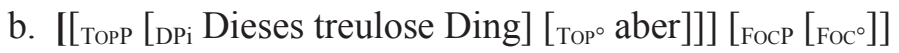

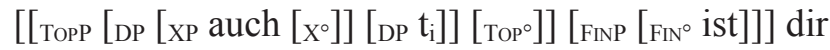
sehr gut gelungen.

c. $\left[\left[\operatorname{TopP}_{\text {Top }}\left[\mathrm{XP} \text { Auch }\left[\mathrm{x}^{\circ}\right][\text { dieses treulose Ding }]\right]\right]_{\text {Top }^{\circ}}\right.$

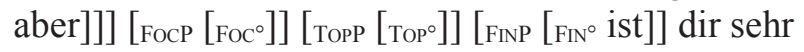
gut gelungen.

At this point, the question arises as to how the facts presented in 22 may be analyzed. Specifically, how split complex DPs with clausal complements (relative, infinitival, or that-clauses), or genitive phrases or PPs can be structurally justified, given that none of the current analyses take this possibility into account. In 29 a, the example in $22 \mathrm{a}$ is reproduced for the reader's convenience. A similar example, in which the complement of the DP is a GenP, is given in $29 \mathrm{~b}$. 
(29) a. Nur die Tatsache aber, daß ein Ereignis only the.NOM fact.NOM however that a.NOM event.NOM

einem anderen zeitlich voraus-geh-t, a.DAT other.DAT temporally V.PRT-precede-3SG.PRS

bedeut-et nicht schon [...].

mean-3SG.PRS NEG already [...]

'Only the fact that an event may precede another temporally does not imply [...]'.

(Schallenberg 2008:210)

b. Die Tatsache aber allein

the.NOM fact.NOM however only

der Krebsentwicklung mahn-t

the.GEN cancer-development.GEN urge-3SG.PRS

zur Vorsicht.

to-the.DAT caution.DAT

'However, only the fact of cancer development urges to caution.'

(Pickroth 1949:385)

Apart from the complement type, an obvious difference between 29a and $29 \mathrm{~b}$ consists in the position of the focus particle. As one can see, even when the XP in clause-initial position is detached from its complement because of the presence of the postinitial particle, the focus particle may intervene after aber. This is particularly interesting, because it shows that the focus particle can only occur in the structural position of the Split CP in which FocP is located. In fact, the placement of the focus particle elsewhere, for example, after the clausal/genitive complement, would lead to ungrammaticality:

(30) a. *Die Tatsache aber, daß ein Ereignis einem anderen zeitlich vorausgeht nur, bedeutet nicht schon $[\ldots]$. 
b. ??Die Tatsache aber der Krebsentwicklung allein mahnt zur Vorsicht.

This strongly supports an analysis such as $28 \mathrm{~b}$, in which the phrase moving into the higher TopP optionally reaches the lower TopP. From the position in the lower TopP, the XP die Tatsache 'the fact' in 29 moves to the higher TopP. In 29a, the focus particle nur 'only' moves up higher together with the DP it resides in. In 29b, the particle remains in the DP, while its N, together with the genitive DP complement, moves out of the lower Top projection. The postinitial particle aber, which is base-generated in $\mathrm{Top}^{\circ}$ and does not move, follows the DP die Tatsache. Indeed, in such cases the lower TopP projection is unavailable for further topics raising to the left periphery from their base position in the middle field, as shows the ungrammaticality of the examples in 31 .

a. *Nur die Tatsache aber, daß ein Ereignis
only the.NOM fact.NOM however that a.NOM event.NOM
einem anderen zeitlich voraus-geh-t,
a.DAT other.WI temporally V.PRT-precede-3SG.PRS

$\begin{array}{llll}\text { im } & \text { Allgemeinen } & \text { bedeut-et } & \text { nicht schon [...]. } \\ \text { in-the.DAT } & \text { general.WI } & \text { mean-3SG.PRS } & \text { NEG already }\end{array}$

b. *Die Tatsache aber allein the.NOM fact.NOM however only

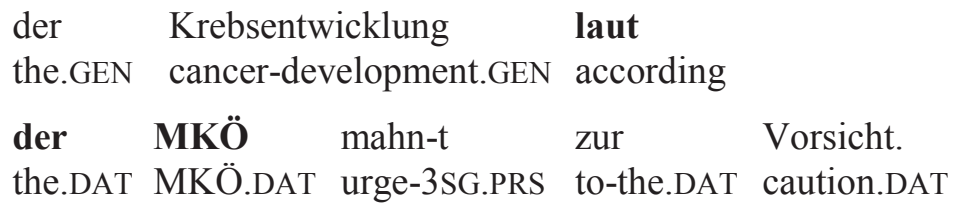

In any case, Volodina \& Weiß' (2010) idea that the particle surfacing in postinitial position may be base-generated in the middle field is not confirmed in an obvious way by empirical evidence. Indeed, it does not matter what specific derivation the authors assign structures of the type $X P+$ postinitial particle in the prefield (that is, the movement of the XP into [Spec, PrtP] and the subsequent raising of the complex phrase into the left periphery). Such particles as aber cannot appear in the middle 
field with the same function, since in a lower position they are always associated with the predicate and not the XP with which they move to TopP. The structural representation assumed here for the "extreme" case of a DP - that is, a DP that occurs in the prefield in combination with a focus particle (in both pre- and postnominal position) and a postinitial particle, whose complement appears after the particle itself-is given in 32. The derivation of the word order in $22 \mathrm{a}$ and $22 \mathrm{~b}$ is given in $32 \mathrm{a}$ and $32 \mathrm{~b}$, respectively.

(32) a. ForceP

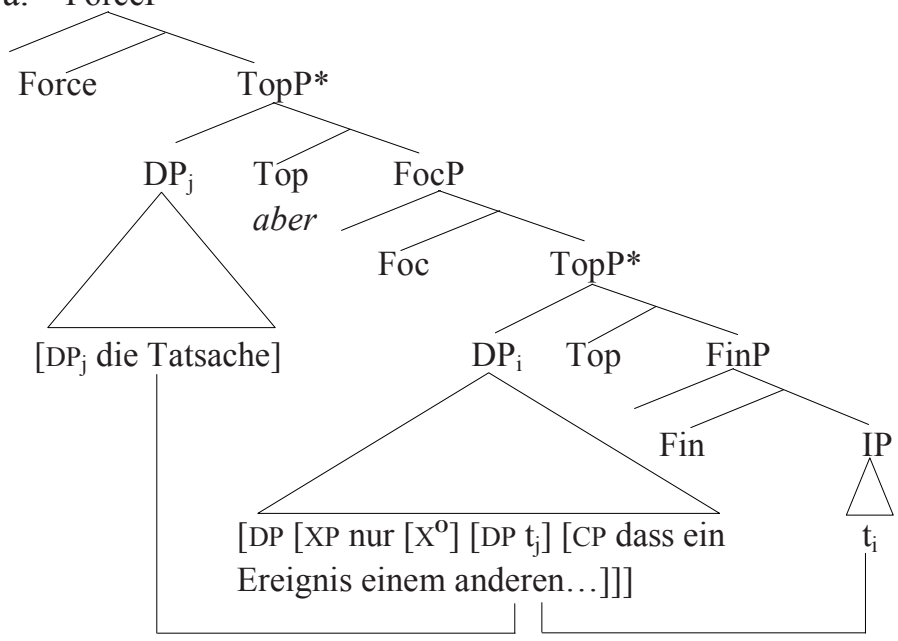


b. ForceP

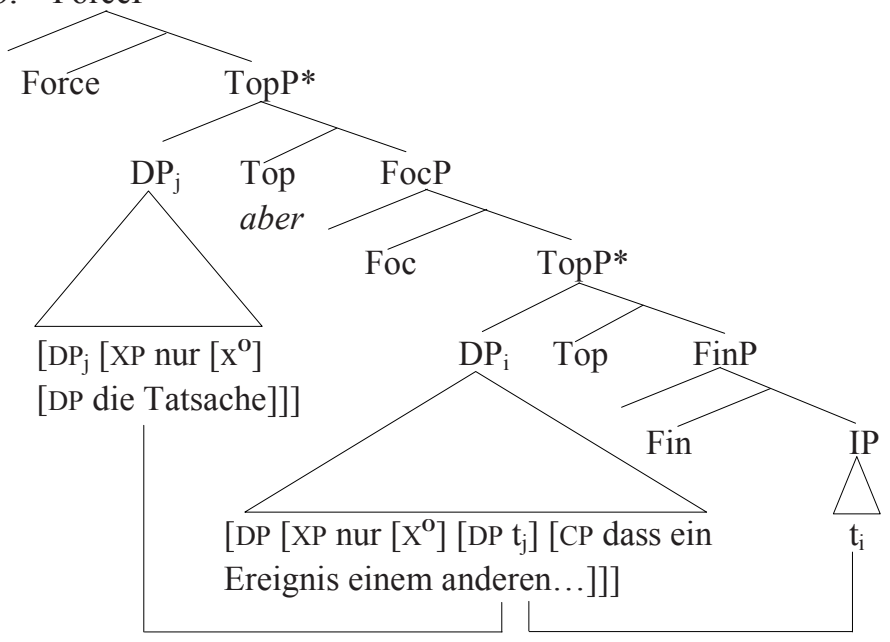

It goes without saying that separating the head from its complement is not obligatory: When they surface in adjoined positions, the word order within the prefield is the same. Consider the example in 33.

(33) Die Tatsache $\left\{{ }^{\mathrm{OK}}\right.$ der Krebsentwicklung $\}$ aber allein $\left\{{ }^{\mathrm{OK}}\right.$ der Krebsentwicklung\} mahnt zur Vorsicht.

Of course, more research is needed to derive a comprehensive and evidence-based picture of the phenomenon. However, this analysis may contribute to further studies, given that it seems to be, mutatis mutandis, unproblematic from a technical point of view. The relevant - and clearly somewhat controversial - implication of such an analysis is that, contrary to the common assumption (excluding the intuitions tested and formalized in Jacobs 1986), the prefield of the German clause is only apparently simple. In fact, the impossibility of finding an elegant account for the bizarre crowding of the preverbal area in such cases - as well as the unjustified assumption that topic and focus particles are basegenerated in the middle field - amounts to the admission that in some cases, the extended CP may host more than one element besides the finite verb and, occasionally, a resumptive pronoun in [Spec, FinP] (that is, the case of left dislocation). 


\section{Summary and Conclusions.}

In the present paper, I considered three cases of apparent multiple filling of the prefield in German, namely, structures in which the preverbal area of the clause seems to be occupied by (i) two full XPs that are clearly base-generated VP-internally (for example, a DP and an adjunct $\mathrm{CP}$, an $\mathrm{AP}$ and a PP, etc.); (ii) an XP base-generated in the middle field and a focus particle (I concentrated on the case of sogar 'even'), with the focus particle appearing either to the right or to the left of the XP; (iii) an XP base-generated in the VP and a motionless postinitial (topic) particle, the latter exemplified by the umbrella case of aber 'however'. Given that German is classified as a strictly V2 language, in which the finite verb always occurs in second position in matrix clauses, in the literature such phenomena are generally treated as cases of apparent multiple filling of the prefield. Although there are some exceptions (see Jacobs 1986), no formal analysis has been proposed.

It was shown that Müller's (2003) remnant VP solution to (i) does not capture all possible scenarios. For example, it does not account for cases where a DP and an adjunct CP are topicalized. The same goes for the interaction of focus particles and postinitial particles, for which a solution has been suggested. Volodina \& Weiß (2010) propose that the linear surface order before the inflected verb in the prefield results from a complex derivation starting in the middle field: The postinitial particle is base-generated in a dedicated projection within the TP, and the XP moves into its specifier. Then the whole PrtP moves higher into the left periphery. Volodina \& Weiß, however, have admittedly not found any solution to structures in which not only a postinitial particle such as aber, but also a focus particle occurs. Furthermore, there seems to be no empirical evidence for the hypothesis that such particles are generated in the middle field.

In any case, none of the analyses available take into consideration complex XPs that move into the prefield and co-occur with a focus particle and a postinitial particle. The latter optionally separates the head of the XP from a complement, which can be a that-clause, a relative clause, a genitive phrase, or a PP. Unlike the topic particle, the focus particle may appear in two positions, namely, either after the topicalized constituent (and the topic particle, if present) or to the left of the XP. For this maximally complex construction, an analysis has been suggested in the present paper that accounts for all possible word orders. It has been 
proposed that the XP (composed, for instance, of a FocPrt-modified DP and its clausal or phrasal complement) optionally moves to the specifier of the lower TopP projection prior to raising to its landing site in the higher [Spec, TopP]. From there, the DP moves to the higher topical projection, its complement remaining in the specifier position of the lower TopP. The postinitial particle, which is base-generated in the head of the higher TopP, may not move and follows, in linear terms, the topicalized XP residing in its specifier. In contrast, the focus particle may either remain in the partially emptied DP in the lower Top position or optionally move to the higher TopP together with its DP.

In cases in which two constituents (for example, a DP and a CP) raise to the prefield, irrespective of whether a focus or topic particle intervenes between them, they are linearized as targeting the higher and the lower TopPs. Such a derivation is able to account for all possible word orders (and also exclude the ungrammatical strings) without violating any constraint on extraction and, crucially, is motivated by the distribution of focus versus postinitial particles.

This analysis shows that the CP area may be occupied by up to two nonverbal items, irrespective of their nature. ${ }^{11}$ Yet by no means does it intend to put into question the validity of the V2 parameter in German, which is clearly active and visible in a number of ways. It suggests instead a more flexible approach to the internal structure of the German clause. Under this approach, so-called exceptions may be accounted for in terms of the cartographic structure we dispose of at least since Rizzi's (1997) seminal formalization of the fine design of the pre-IP layer. According to Rizzi's analysis, the pre-IP layer contains as many FPs (and corresponding grammatical functions) as are needed to satisfactorily explain the presence of multiple constituents in the left periphery.

${ }^{11}$ In Müller (2003), examples are discussed in which apparently more than two elements are present in the left periphery: [Gezielt] [Mitglieder] [im Seniorenbereich] wollen die Kendoka allerdings nicht werben. 'The kendokas don't want to specifically promote the members at senior level.' or [Endlich] [Ruhe] [in die Sache] brachte die neue deutsche Schwulenbewegung zu Beginn der siebziger Jahre. 'At the beginning of the 70's the new German gay movement finally brought the situation to a standstill.' However, such examples represent clear cases of remnant VPs: The relevant point here is that, as shown above, the attestations discussed in this paper are not justifiable by means of a remnant VP analysis. 


\section{REFERENCES}

Altmann, Hans. 1981. Formen der "Herausstellung” im Deutschen: Rechtsversetzung, Linksversetzung, freies Thema und verwandte Konstruktionen (Linguistische Arbeiten 106.). Tübingen: Niemeyer.

Anderson, Curt. 2014. Hedging verbs and nouns using an alternative semantics. Proceedings of ConSOLE XXI, ed. by Martin Kohlberger, Kate Bellamy, \& Eleanor Dutton, 1-20. Leiden: Leiden University Centre for Linguistics.

Auer, Peter. 1998. Zwischen Parataxe und Hypotaxe: "Abhängige Hauptsätze" im gesprochenen und geschriebenen Deutsch. Zeitschrift für Germanistische Linguistik 26. 284-307.

Bech, Kristin, \& Kristine Gunn Eide (eds.). 2014. Information structure and syntactic change in Germanic and Romance languages. Amsterdam: John Benjamins.

Bierwisch, Manfred. 1963. Grammatik des deutschen Verbs. Berlin: AkademieVerlag.

Bildhauer, Felix. 2011. Mehrfache Vorfeldbesetzung und Informationsstruktur. Eine Bestandsaufnahme. Deutsche Sprache 4. 362-379.

Blakemore, Diane. 2000. Indicators and Procedures: nevertheless and but, Journal of Linguistics 36. 463-486.

Blühdorn, Hardarik. 2012. Zur Syntax adverbialer Satzverknüpfungen: Deutsch - Italienisch - Portugiesisch. Deutsch im Sprachvergleich. Grammatische Kontraste und Konvergenzen, ed. by Lutz Gunkel \& Gisela Zifonun, 301-332. Berlin: de Gruyter.

Borsley, Robert. 2005. Against ConjP. Lingua 115. 461-482

Breindl, Eva. 2008. Die Brigitte nun kann der Hans nicht ausstehen. Gebundene Topiks im Deutschen. Erkenntnisse vom Rande. Zur Interaktion von Prosodie, Informationsstruktur, Syntax und Bedeutung. Zugleich Festschrift für Hans Altmann zum 65. Geburtstag (Themenheft Deutsche Sprache 1/2008), ed. by Eva Breindl \& Maria Thurmair, 27-49. Berlin: Schmidt.

Breindl, Eva. 2011. Nach Rom freilich führen viele Wege: Zur Interaktion von Informationsstruktur, Diskursstruktur und Prosodie bei der Besetzung der Nacherstposition. Konnektoren, ed. by Gisella Ferraresi, 1-40. Tübingen: Narr.

Bühring, Daniel, \& Katharina Hartmann. 2001. The syntax and semantics of focus-sensitive particles in German. Natural Language and Linguistic Theory 19. 229-281.

Cardinaletti, Anna. 1989. Linksperiphere Phrasen in der deutschen Syntax. Studium Linguistik 22. 1-30.

Chafe, Wallace. 1976. Givenness, contrastiveness, definiteness, subjects, topics and points of view. Subject and topic, ed. by Charles Li, 27-55. New York, NY: Academic Press. 
Cinque, Guglielmo, \& Luigi Rizzi. 2010. The cartography of syntactic structures. The Oxford handbook of linguistic analysis, ed. by Bernd Heine \& Heiko Narrog, 51-65. Oxford: Oxford University Press.

Coniglio, Marco. 2006. German modal particles in the functional structure of IP. University of Venice Working Papers in Linguistics 16. 57-95.

Daneš, Frantisek. 1974. Functional sentence perspective and the organization of the text. Papers on functional sentence perspective, ed. by Frantisek Daneš, 106-128. Prague: Academia.

Den Besten, Hans. 1983 [1977]. On the interaction of root transformations and lexical deletive rules. On the formal syntax of the Westgermania, ed. by Werner Abraham, 47-131. Amsterdam: John Benjamins.

Drach, Erich. 1963 [1937]. Grundgedanken der deutschen Satzlehre. Darmstadt: Wissenschaftliche Buchgesellschaft.

Eroms, Hans-Werner, Gerhard Stickel, \& Gisela Zifonun (eds.). 1997. Grammatik der deutschen Sprache. Berlin: de Gruyter.

Fanselow, Gisbert. 1987. Konfigurationalität (Studien zur deutschen Grammatik 29). Tübingen: Narr.

Fanselow, Gisbert. 1993. Die Rückkehr der Basisgenerierer. Groninger Arbeiten zur Germanistischen Linguistik 36. 1-74.

Ferraresi, Gisella. 2008. Adverbkonnektoren: Von der Theorie zur Praxis. Auf neuen Wegen: Deutsch als Fremdsprache in Forschung und Praxis (Materialien Deutsch als Fremdsprache 79.), ed. by Christoph Chlosta, Gabriela Leder, \& Barbara Krischer, 173-186. Göttingen: Universitätsverlag. Fourquet, Jean Philippe. 1957. Review of Heinz Anstock, Deutsche SyntaxLehr- und Übungsbuch. Wirkendes Wort 8. 120-122.

Fourquet, Jean Philippe. 1970. Prolegomena zu einer deutschen Grammatik. Düsseldorf: Pädagogischer Verlag Schwann.

Frascarelli Mara, \& Roland Hinterhölzl. 2007. Types of topics in German and Italian. On information structure, meaning and form, ed. by Susanne Winkler \& Kerstin Schwabe, 87-116. Amsterdam: John Benjamins.

Gaeta, Livio. 2010. The invisible hand of grammaticalization: West-Germanic substitutive infinitive and the prefix ge-. Variation and change in morphology. Selected papers from the 13th International Morphology Meeting, ed. by Franz Rainer, Wolfgang U. Dressler, Dieter Kastovsky, \& Hans Christian Luschützky, 89-105. Amsterdam: John Benjamins.

Haegeman, Liliane. 2004. The Syntax of Adverbial Clauses and its Consequences for Topicalisation. Antwerp Papers in Linguistics 107. 61-90.

Haegeman, Liliane. 2013. Two prenominal possessors in West Flemish. Morphosyntactic categories and the expression of possession (Linguistik Aktuell 199), ed. by Kersti Börjars, David Denison, \& Alan Scott, 219-251. Philadelphia: John Benjamins. 
Haider, Hubert. 1982. Dependenzen und Konfigurationen: Zur deutschen VProjektion. Groninger Arbeiten zur Germanistischen Linguistik 21. 1-60. Hinterhölzl, Roland. 2009. The role of information structure in word order variation and word order change. Information structure and language change: New approaches to word order variation in Germanic, ed. by Roland Hinterhölzl \& Svetlana Petrova, 45-66. Berlin: de Gruyter.

Hinterhölzl, Roland. 2014. On the interaction between syntax, prosody and information structure: An interface approach to word order developments in Germanic. Bech \& Gunn Eide 2014, 341-376.

Höhle, Tilman. 1986. Der Begriff „Mittelfeld“, Anmerkungen über die Theorie der topologischen Felder. Akten des Siebten Internationalen Germanistenkongresses 1985, ed. by Albrecht Schöne, 329-340. Tübingen: Niemeyer.

Jacobs, Joachim. 1983. Fokus und Skalen. Zur Syntax und Semantik der Gradpartikeln im Deutschen. Tübingen: Niemeyer.

Jacobs, Joachim. 1986. The syntax of focus and adverbials in German. Topic, focus, and configurationality, ed. by Werner Abraham \& Sjaak de Meij, 103127. Philadelphia: John Benjamins.

Jensen, Christine Franziska. 2012. Die mehrfache Vorfeldbesetzung im Deutschen. Tromsø, Norway: University of Tromsø MA thesis.

Karagjosova, Elena. 2012. On the discourse function of particles in post-initial position. Lingua 122. 1819-1842.

Kiziak, Tanja. 2007. Long extraction or parenthetical insertion? Evidence from judgement studies. Parentheticals, ed. by Nicole Dehé \& Yordanka Kovalova, 121-144. Philadelphia: John Benjamins.

Kleemann, Anja. 2007. Focus particle placement within German event nominals. Queen Mary's Occasional Papers Advancing Linguistics 10. 1-16.

Métrich, René, \& Gilbert Courdier, 1995. Die Zukunft des Menschen aber ist immer so lang wie seine Vergangenheit. Rand und Band. Abgrenzung und Verknüpfung als Grundtendenzen des Deutschen. Festschrift für Eugene Faucher zum 60. Geburtstag (Eurogermanistik 7), ed. by René Métrich \& Marcel Vuillaume, 29-38. Tübingen: Narr.

Müller, Gereon. 1998. Incomplete Category Fronting. A Derivational Approach to Remnant Movement in German (Studies in Natural Language and Linguistic Theory 42). Dordrecht/Boston/London: Kluwer Academic Publishers.

Müller, Stefan. 2003. Mehrfache Vorfeldbesetzung. Deutsche Sprache 31. 2962.

Müller, Stefan. 2005. Zur Analyse der deutschen Satzstruktur. Linguistische Berichte 201. 3-39.

Müller, Stefan. 2013. Datensammlung zur scheinbar mehrfachen Vorfeldbesetzung. Unpublished manuscript, Freie Universität Berlin. 
Available at http://hpsg.fu-berlin.de/ stefan/PS/mehr-vf-daten.pdf, accessed on August 17, 2014.

Müller, Stefan, Felix Bildhauer, \& Philippa Cook. 2012. Beschränkungen für die scheinbar mehrfache Vorfeldbesetzung im Deutschen. Satzeröffnung:

Formen, Funktionen, Strategien (Eurogermanistik 31.), ed. by Colette Cortes, 113-128. Tübingen: Stauffenburg Verlag,

Nolda, Andreas. 2004. Topics detached to the left: On 'left dislocation', 'hanging topic', and related constructions in German. ZAS Papers in Linguistics 35. 423-448.

Onea, Edgar \& Klaus von Heusinger. 2009. Grammatical and contextual restrictions on focal alternatives. Focus and Background in Romance Languages, ed. by Daniel Jacob \& Andreas Dufter, 281-308. Amsterdam: John Benjamins.

Pasch, Renate, Ursula Brauße, Eva Breindl, \& Ulrich Hermann Waßner. 2003. Handbuch der deutschen Konnektoren. Berlin: de Gruyter.

Pollock, Jean-Yves. 1989. Verb movement, Universal Grammar and the structure of IP. Linguistic Inquiry 20. 365-424.

Pysz Agnieszka, \& Bartosz Wiland. 2012. The shift to strict VO in English at the PF Interface. Comparative Germanic syntax: The state of the art, ed. by Peter Ackema, Rhona Alcorn, Caroline B. Heycock, Dany Jaspers, Jeroen van Craenenbroeck, \& Guido J. Vanden Wyngaerd, 311-352. Amsterdam: John Benjamins.

Reis, Marga. 1997. Zum syntaktischen Status unselbständiger Verbzweit-Sätze. Sprache im Fokus. Festschrift für Heinz Vater zum 65. Geburtstag, ed. by Christa Dürscheid, Karl-Heinz Ramers, \& Monika Schwarz, 121-144. Tübingen: Niemeyer.

Reis, Marga. 2005. On the syntax of so-called focus particles in German: A reply to Büring and Hartmann 2001. Natural Language and Linguistic Theory 23. 459-483.

Rizzi, Luigi. 1997. The fine structure of the left periphery. Elements of grammar, ed. by Liliane Haegeman, 281-337. Amsterdam: Kluwer.

Sæbø, Kjell Johan. 2003. Presupposition and contrast: German "aber" as a topic particle. Proceedings SuB7, ed. by Matthias Weisgerber, 257-271. Constance: University of Constance.

Sapp, Christopher. 2011. The verbal complex in subordinate clauses from Medieval to Modern German (Linguistik Aktuell 173). Philadelphia: John Benjamins.

Schallert, Oliver. 2014. Zur Syntax der Ersatzinfinitivkonstruktion (Studien zur deutschen Grammatik 87). Tübingen: Stauffenburg.

Schwartz, Bonnie, \& Sven Vikner. 1996. The verb always leaves IP in V2 clauses. Parameters and functional heads, ed. by Adriana Belletti \& Luigi Rizzi, 11-62. Oxford: Oxford University Press. 
Speyer, Augustin. 2008. Doppelte Vorfeldbesetzung im heutigen Deutsch und im Frühneuhochdeutschen. Linguistische Berichte 216. 455-485.

Sudhoff, Stefan. 2010. Fokuspartikeln innerhalb von DPn im Deutschen. 40 Jahre Partikelforschung, ed. by Theo Harden \& Elke Hentschel, 169-181. Tübingen: Stauffenburg.

Thiersch, Craig Lee. 1978. Topics in German syntax. Cambridge, MA: MIT doctoral Dissertation.

Volodina, Anna, \& Helmut Weiß. 2010. Wie einfach ist das deutsche Vorfeld?, Paper presented at GGS 2010, FU Berlin. IDS Mannheim/Goethe-Universität Frankfurt a.M. Available at http://www.annavolodina.de/dokumente/ Vortrag_GGS_naemlich_7-05_lit.pdf, accessed on April 12, 2015.

Watanabe, Akira. 2006. Functional projections of nominals in Japanese: Syntax of classifiers. Natural Language and Linguistic Theory 24. 241-306.

\section{DATA SOURCES}

Anonymous. 1830. Die heiligen Evangelien und Episteln oder Lektionen auf alle Sonn- und Festtage des Jahres zum Gebrauche der Schulen. Regensburg: Johann Baptist Rotermundt.

Archiv für Gesprochenes Deutsch (AGD), Zwirner-Korpus, 1957. Available at http://agd.ids-mannheim.de/, accessed on April 12, 2015.

COSMIQ-Die Wissenscommunity (online forum). Fragen, March 29, 2013. Available at http://www.cosmiq.de/qa/show/3558242/, accessed on April 12, 2015.

Der Spiegel. 1960 (43). Available at http://www.spiegel.de/spiegel/print/index1960-43.html, accessed on April 12, 2015.

Der Spiegel Online. November 20, 2013. Microsofts Xbox One im Test: Schwarz, teuer, stark. Available at http://www.spiegel.de/netzwelt/games/ microsofts-xbox-one-im-test-a-934536.html, accessed on June 1, 2015.

Der Spiegel Online. May 12, 2014. Debatte über Abbruch-Fonds: Was E.on und Co. mit ihren Atommeilern verdient haben. Available at http://www.spiegel.de/wirtschaft/unternehmen/atomkraft-was-eon-und-comit-ihren-atomeilern-verdienten-a-968941.html, accessed on April 12, 2015.

Die Oberbadische (online newspaper). Schopfheim-Trauer passt in keine Schablone, September 4, 2013. Available at http://www.verlagshausjaumann.de/inhalt.schopfheim-trauer-passt-in-keine-schablone.1dd0fc113771-4b97-a4ec-72dd96354a99.html, accessed on April 12, 2015.

Die Presse.com., Niederösterreich zehrte 2011 von Geldreserven, March 28, 2012. Available at http://diepresse.com/home/politik/innenpolitik/ 744483/Niederosterreich-zehrte-2011-von-Geldreserven, accessed on April $12,2015$. 
Die weißen Wölfe (online blog). April 20, 2010. Zoom World Gelsenkirchen. Available at http://www.xn--die-weissen-wölfe-ywb.de/, accessed on March 10, 2015.

Die Welt (online newspaper). July 31, 2011. Fiat Mefistofele-Mit dem Motor eines Kampffliegers zum Weltrekord. Available at http://www.welt.de/motor/article13505799/Mit-dem-Motor-einesKampffliegers-zum-Weltrekord.html, accessed on April 12, 2015.

Die Zeit. 1987 (19). Anlageprofis unter Erfolgsdruck, May 1, 1987. Available at http:// http://www.zeit.de/1987/19/anlageprofis-unter-erfolgsdruck, accessed on September 15, 2015.

Die Zeit. 2000 (33). Ein Verbot hilft der NPD Warnung vor falschem Aktionismus, August 10, 2000. Available at http://www.zeit.de/2000/33/ Ein_Verbot_hilft_der_NPD, accessed on April 12, 2015.

Dölle, Frank. 2013. Generation 601. Norderstedt: BOD.

Gameland (online forum). Review of the movie The fifth sense. Available at http://gameland.waraxe.us/dvd-491.html, accessed on April 12, 2015.

Herbart, Johann Friedrich. 1816. Lehrbuch zur Pychologie. Königsberg: Unzer. Humboldt, Wilhelm von. 1956 [1809]. Über die innere und äußere Organisation der höheren wissenschaftlichen Anstalten in Berlin. Die Idee der deutschen Universität. Die fünf Grundschriften aus der Zeit ihrer Neubegründung durch klassischen Idealismus und romantischen Idealismus, ed. by Ernst Anrich, 375-386. Darmstadt: Gentner.

Jahbuch z'Rieche. June 2, 2013. Autoren aus Riehen: Felix Philipp Ingold. Available at www.zrieche.ch/de/archiv/.../autoren-aus-riehen-felix-philippingold.html, accessed on April 12, 2015.

Ketter, Helena. 2002. Zum Bild der Frau in der Malerei des Nationalsozialismus: Eine Analyse von Kunstzeitschriften aus der Zeit des Nationalsozialismus. Münster: Lit.

Koch-Grünberg, Theodor. 2009. Vom Roroima zum Orinoco: Ergebnisse einer Reise in Nordbrasilien und Venezuela in den Jahren 1911-1913, vol. 2: Mythen und Legenden der Taulipang- und Arekuna-Indianer. Cambridge: Cambridge University Press.

Khvolson, Daniil Avraamovich. 2011 [1859]. Über die Überreste: Der Altbabylonischen Literatur in Arabischen Übersetzungen. Cambridge: Cambridge University Press.

Montségur Autorenforum, September 26, 2012. Dialekt -Streitpunkt in Verlag, unter Autoren, Buchhändlern und Lesern. Available at http://montsegur.de/ ipb-forum/index.php/topic/15236-dialekt-streitpunkt-in-verlag-unter-autorenbuchh\%C3\%A4ndlern-und-lesern/page-3, accessed on August 3, 2014.

Nietzsche, Friedrich. 1955 [1883-1885]. Also sprach Zarathustra: Ein Buch für Alle und Keinen. Friedrich Nietzsche. Werke in drei Bänden, vol. 2, ed. by Karl Schlechta, 275-561. München: Carl Hanser. 
Pickroth, Gustav. 1949. Abstract Mastopathia cystica chronica im Hinblick auf krebsige Entartung. Langenbecks Archiv für klinische Chirurgie, 262. 385389.

Sigfried Poller. 2008. Wohin geht die Reise, Deutschland? Münster: MV-Verlag.

Schalit, Abraham. 2001. König Herodes. Der Mann und sein Werk. Berlin: de Gruyter.

Schallenberg, Magnus. 2008. Freiheit und Determinismus. Ein philosophischer Kommentar zu Ciceros Schrift De fato. Berlin: de Gruyter.

Schlosser, Johann Georg. 1972 [1798]. Aristoteles Politik und Fragment der

Oeconomik: Aus dem Griechischen übersetzt und mit Anmerkungen und einer Analyse des Textes versehen. Lübeck/Leipzig: Bohn.

von Siebold, Eduard Caspar Jacob. 1835. Abbildungen aus dem Gesammtgebiete der theoretisch-praktischen Geburtshülfe, 2nd edn. Berlin: Herbig.

taz.de (online newspaper). September 22, 2009. Wie hört man heute die im Osten sozialisierte Musik? Available at http://www.taz.de/1/archiv/digitaz/ artikel/?ressort=tp \&dig=2009\%2F09\%2F 22\%2Fa0072\&cHash=ee40da34f2, accessed on June 9, 2015.

Westle, Bettina. 2009. Warum sollen wir Sie wählen, Frau Merkel? Analyse zum "feministischen Wahldilemma". Wähler in Deutschland: Sozialer und politischer Wandel, Gender und Wahlverhalten, ed. by Kühnel, Steffen, Oskar Niedermayer, \& Bettina Westle, 228-260. Wiesbaden: VS Verlag für Sozialwissenschaften.

Weyhenmayer, Johann Heinrich. 1701. Tragoedia Tragoediarum, oder TrauerSpiel über alle Trauer-Spiele. Leipzig: Johan Ludwig Gleditsch.

Zeitung für die elegante Welt. 1859 [1801]. Zeitung für die elegante Welt Berlin: Mode, Unterhaltung, Kunst, Theater, vol. 20-26, ed. by Karl Spazier, 10771084. Berlin: Janke.

\section{Ludwig-Maximilians-Universität}

Fakultät für Sprach- und Literaturwissenschaften

Department I -

Germanistik, Komparatistik, Nordistik, Deutsch als Fremdsprache

Geschwister-Scholl-Platz 1

80539 München

Germany

[nicholas.catasso@campus.lmu.de] 